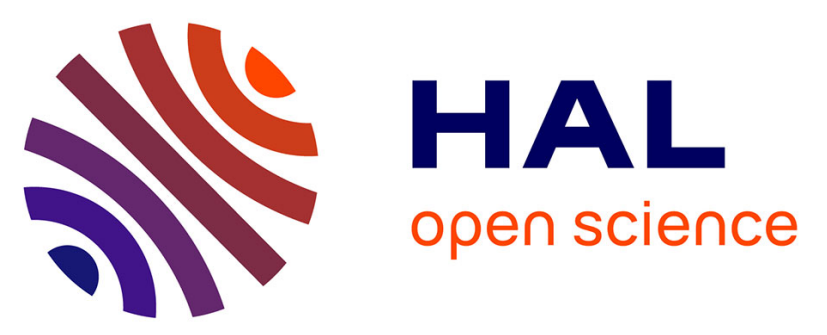

\title{
A fluvial record of the mid-Holocene rapid climatic changes in the middle Rhone valley (Espeluche-Lalo, France) and of their impact on Late Mesolithic and Early Neolithic societies
}

Jean-François Berger, Claire Delhon, Frédéric Magnin, Sandrine Bonte, Dominique Peyric, Stephanie Thiebault, Raphaële Guilbert, Alain Beeching

\section{To cite this version:}

Jean-François Berger, Claire Delhon, Frédéric Magnin, Sandrine Bonte, Dominique Peyric, et al.. A fluvial record of the mid-Holocene rapid climatic changes in the middle Rhone valley (Espeluche-Lalo, France) and of their impact on Late Mesolithic and Early Neolithic societies. Quaternary Science Reviews, 2016, 136 (SI), pp.66-84. 10.1016/j.quascirev.2015.11.019 . hal-01444687

\author{
HAL Id: hal-01444687 \\ https://hal.science/hal-01444687
}

Submitted on 15 Feb 2022

HAL is a multi-disciplinary open access archive for the deposit and dissemination of scientific research documents, whether they are published or not. The documents may come from teaching and research institutions in France or abroad, or from public or private research centers.
L'archive ouverte pluridisciplinaire HAL, est destinée au dépôt et à la diffusion de documents scientifiques de niveau recherche, publiés ou non, émanant des établissements d'enseignement et de recherche français ou étrangers, des laboratoires publics ou privés. 


\title{
A fluvial record of the mid-Holocene rapid climatic changes in the middle Rhone valley (Espeluche-Lalo, France) and of their impact on Late Mesolithic and Early Neolithic societies
}

\author{
Jean-François Berger ${ }^{\text {a, }}{ }^{*}$, Claire Delhon ${ }^{\text {b}}$, Frédéric Magnin ${ }^{c}$, Sandrine Bonté ${ }^{\mathrm{d}}$, \\ Dominique Peyric ${ }^{\mathrm{e}}$, Stéphanie Thiébault ${ }^{\mathrm{f}}$, Raphaele Guilbert ${ }^{\mathrm{g}}$, Alain Beeching ${ }^{\mathrm{h}}$ \\ a Université de Lyon, CNRS, Université Lyon 2-Lumière, UMR 5600 EVS, F-69007, France \\ ${ }^{\mathrm{b}}$ Univ. Nice Sophia Antipolis, CNRS, CEPAM, UMR 7264, F-06300 Nice, France \\ ' IMBE, Aix-Marseille Université, CNRS, IRD, Avignon Université, Europôle Méditerranéen de l'Arbois, BP 80, F-13545 Aix-en-Provence Cedex 4, France \\ d 10 place Achille Jubinal, 65200 Bagneres de Bigorre, France \\ e Musée Pierre Martel de Vachères, F-04110 Vachères, France \\ ${ }^{\mathrm{f}}$ Muséum national d'Histoire naturelle, CNRS, Archéozoologie, Archéobotanique, UMR 7209, F-75005 Paris, France \\ ${ }^{\mathrm{g}}$ Université de Lyon, INRAP, Université Lyon 2-Lumière, UMR 5133 Archéorient, F-69007, France \\ ${ }^{\mathrm{h}}$ Université de Lyon, Université Lyon 2-Lumière, MOM-UMR 5133 Archéorient, F-69007, France
}

A R T I C L E I N F O

Article history:

Received 8 April 2015

Received in revised form

11 November 2015

Accepted 30 November 2015

Available online $\mathrm{xxx}$

Keywords:

Mid-Holocene

Rapid climatic change

8.2 and $7.7 / 7.1$ events

Middle Rhone valley

fluvial metamorphosis

Palaeosoil

Early Neolithic

Ecological successions

\begin{abstract}
A B S T R A C T
This multi-proxy study of a small floodplain in the Rhone catchment area, at the northern edge of the Mediterranean morphoclimatic system, provides valuable information concerning the impact of midHolocene climate variability (8.5-7.0 ka) and the effects of two rapid climatic changes (8.2 and 7.7/7.1 $\mathrm{ka}$ ) on an alluvial plain, its basin and the first farming societies of the Rhone valley. Around 7.7/7.1 ka, the combined effects of (1) a strong rate of change in insolation and (2) variations in solar activity amplified marine and atmospheric circulation in the north-west Atlantic (Bond event 5b), which imply continental hydrological, soil and vegetation changes in the small catchment area. For this period, strong fluctuations in the plant cover ratio have been identified, related to a regime of sustained and regular fires, as well as abundant erosion of the hill slopes and frequent fluvial metamorphoses which led to braiding of the watercourse in this floodplain. There are few data available to evaluate the impact of natural events on prehistoric communities. This continental archive offers clear multi-proxy data for discussion of these aspects, having 4 cultural layers interbedded in the fluvial sequence (1 Late Mesolithic, 3 Cardial/ Epicardial). Earlier data indicate the difficulty in recognizing such cultural features in the low alluvial plains of southern France during the Mesolithic/Early Neolithic transition, which should lead to caution when developing settlement models for this period.
\end{abstract}

\section{Introduction}

There is very little precise geomorphological and palaeohydrological data for the Middle Holocene in the north-west Mediterranean basin, where the Neolithic colonization front known as Impressa-Cardial developed between 7.8 and $6.8 \mathrm{ka}$. Moreover, the links between the transformation of river systems and climatic changes at high temporal resolution are still barely known. However, since the Rapid Climatic Changes (RCC) of the

\footnotetext{
* Corresponding author.

E-mail address: Jean-Francois.Berger@univ-lyon2.fr (J.-F. Berger).
}

Holocene have been confirmed on a hemispheric scale (Alley et al., 1997; Mayewski et al., 2004; Magny, 2004; Fleitmann et al., 2007, Combourieu-Nebout et al., 2013), firmly correlated to Bond events in the North Atlantic (Bond et al., 2001), the variability of the climate and of the continental ecosystems has become controversial, particularly concerning the mid-Holocene 'thermal maximum' (also designated as Atlantic period) which is still considered to be a long period of stability for landscapes and watercourses. Most of the scientific publications concern the 8.2 ky event, which is the best known and best recorded of the Holocene RCCs (Baldini et al., 2002; Magny et al., 2003; Alley and Agustsdottir, 2005; Rohling and Pälike, 2005; Weninger et al., 2006; Berger and Guilaine, 2009). The other oscillations in the first half of the Holocene, identified in 
the polar ice fields, are rarely detected or dated in the continental ecosystems (Hoek and Bos, 2007; Fleitmann et al., 2008).

Lacustrine data are useful for the establishment of age models, providing the advantage of detailed chronology. These data come mainly from the continental Alpine region (Jura, northern Alps, Swiss plateau, Bavaria, northern Italy) (Kalis et al., 2003; Magny, 2004). In the Mediterranean area these data are mainly concentrated in Italy (Sadori and Narcisi, 2001, Magny et al., 2007, 2012), Turkey (Roberts et al., 2008) and secondarily in the Iberian peninsula (Carrión, 2002). The latest results show palaeo-hydrological variations strongly related to the climatic fluctuations in the northern hemisphere, which are connected to variations in solar activity and ocean circulation (Magny et al., 2003).

Alluvial valley landforms are the geomorphic expression of river response to combined internal (autogenic) controls and changes in external (allogenic) forcing factors (Erkens et al., 2009). Studies of the Rhone river region (Bravard et al., 1997; Bravard, 2010) and other regions (Starkel, 1983; Brown, 1997; Macklin, 1999) have demonstrated that changes in the type and output of a river are good indicators of the hydro-climatic evolution in the drainage basins. However, concerning the first millennia of the Holocene, which correspond to the optimum of landscape stabilization by vegetation, the fluvial chronology is often not accurate enough to match this period with the chronocultural framework established by archaeology for the last hunter-gatherers and the first agricultural societies. This information gap is mainly due to (1) a frequently imprecise chronology for valley fills (limited ${ }^{14} \mathrm{C}$, too large sampling interval ...), still partly based on palynological evidence, which may provide reliable points of reference but cannot replace absolute dating (Kozarski, 1991; Dambeck and Thiemeyer, 2002), (2) the poor preservation of the alluvial records from this period, because of later riverbed evolution, often characterized by high mobility and torrential features in the north-west Mediterranean region (Berger, 2006, 2011), and finally (3) to the difficulties of accessing the fluvial records for this period, which are deeply buried, particularly in coastal environments (deltas and rias) (Arnaud-Fassetta et al., 2005; Vött et al., 2006). There are new opportunities for detection of Holocene oscillations through the very high chronological resolution of channel filling (Toonen et al., 2012; Salvador and Berger, 2014).

Indeed, some regional studies carried out in central Europe have diagnosed fluctuations in watercourses during the Early Holocene based on morphodynamic and sedimentary criteria: Kalicki (2006) in Poland and Bielorussia, Becker and Schirmer (1977) as well as Delorme and Leuschner (1983), through the study of sub-fossil oak trunks deposited in Holocene valley fills in south-west Germany. Recently, quantitative studies carried out using cumulative probability distribution functions (CPDF) of ${ }^{14} \mathrm{C}$ ages pinpointed the major Holocene hydrological events in large areas or countries, especially for the mid-Holocene (Great Britain, Germany, Poland, Tunisia) (Starkel et al., 2006; Hoffmann et al., 2008; Zielhofer and Faust, 2008; Macklin et al., 2010).

In the Rhone catchment area $\left(100,000 \mathrm{~km}^{2}\right)$, the region of Lyon has produced much evidence thanks to rescue archaeology (Bravard et al., 1997; Berger et al., 2008); the high marly basins of the Durance river system in the limestone pre-Alps in southern France, which were highly sensitive to the palaeoclimatic variations of the early Holocene, present sequences that have been accurately dated by dendrochronology (Sivan and Miramont, 2008); the upper Rhone area, around Lake Bourget, provides evidence for major welldefined and regular detrital events in the northern slopes of the Alps (Arnaud et al., 2005, 2012) (Fig. 1A). Elsewhere, the first half of the Holocene has attracted little research except for some studies on the early/mid-Holocene in the southern Mediterranean (Tunisia and Morocco) along riverbanks that were deeply incised during the
Late Holocene (Zielhofer and Faust, 2008).

The purpose of this paper is to present the results of a multiproxy study based on a transverse section of the Citelle alluvial plain (middle Rhone Valley, France) carried out in the course of the excavation of the Lalo archaeological site, at Espeluche (Drôme). The alluvial terrace consists of a 3-m-thick sedimentary load and is located $2 \mathrm{~m}$ above the current plain of the Citelle river (Fig. 2). It contains a thick fluvial sequence for the period 8.5-7.0 ka. The preservation of the pedosedimentary archive is due to an overbank flow of the Citelle river linked to a general entrenchment of the river system around $7 \mathrm{ka}$, equivalent to the incision that revealed the "main Holocene fill" in the Durance catchment area (Jorda et al., 2002).

The section also revealed cultural horizons that are rarely found other than in karst cavities in the north-western Mediterranean (Castelnovian Late Mesolithic and several Cardial/Epicardial Early Neolithic layers) (Guilaine, 1996). Unfortunately, the open-air Neolithic sites in the western Mediterranean are "flat" in the alluvial plains and are thus difficult and even impossible to detect with traditional survey methods. Their presence demonstrates the incomplete state of regional archaeological archives and represents an opportunity for the local chronostratigraphic building and the discussion of hydrogeomorphological impacts on mid-Holocene settlement systems.

\subsection{Environmental and archaeological contexts}

\subsubsection{Geological, hydrological and bioclimatic context}

The Citelle basin forms the lower part of the Jabron and Roubion catchment areas (total $610 \mathrm{~km}^{2}$ ) and extends over more than $27 \mathrm{~km}^{2}$ in the middle Rhone, east of the city of Montélimar. It culminates at $495 \mathrm{~m}$ in the foothills of the calcareous French preAlps (Fig. $1 \mathrm{~A}$ and B). This river is the major left bank tributary of the Jabron river, which joins the Roubion river at the point of its confluence with the Rhone (Fig. 1B). The Citelle basin consists principally of Secondary marine formations and of Tertiary (Oligocene) lacustrine formations which lie discordantly upon the marine formations towards the south, near the Aleyrac-Montjoyer plateau. In the middle and upper parts of the catchment area, the marls of soft glauconite sandstone and sand are very erodible and abundant. On abrupt slopes, they form typical badlands, currently in a phase of stabilization by the vegetation cover. The downstream part of the basin, where Lalo is located, is mainly composed of Quaternary formations: very gravelly terraces or alluvial fans, under red, slightly fersiallitic or leached brown soils. The site is found some metres above the present-day alluvial plain, on an early Holocene terrace, in the apex of the Holocene alluvial fan of the Citelle river (Fig. 1B). The basin of the Citelle presents high slopes, which explains the reactivity of the hydrological system during the Holocene.

It is located in the Mediterranean climatic zone influenced by tropical high pressure but at the edges of the medio-European and Alpine climatic influences, which are influenced by the westerlies throughout the year. The climate is thus transitional between the Mediterranean, continental and Atlantic climates. The total average annual precipitation is $900 \mathrm{~mm}$, with important annual variations (300-1700 mm) and a high inter-annual variability in precipitation pattern (Blanchet, 1990). The area is affected by an attenuated Mediterranean summer drought (1-2 months of water deficit according to the Thornthwaite water balance) with concentration of rainfalls in autumn and spring. The vegetation of the Citelle basin is typical of the supra-Mediterranean stage. Besides cultivated areas, deciduous oak (Quercus pubescens) formations and degradation facies characterised by the abundance of box (Buxus sempervirens) are characteristic of the middle Rhone valley landscape. 


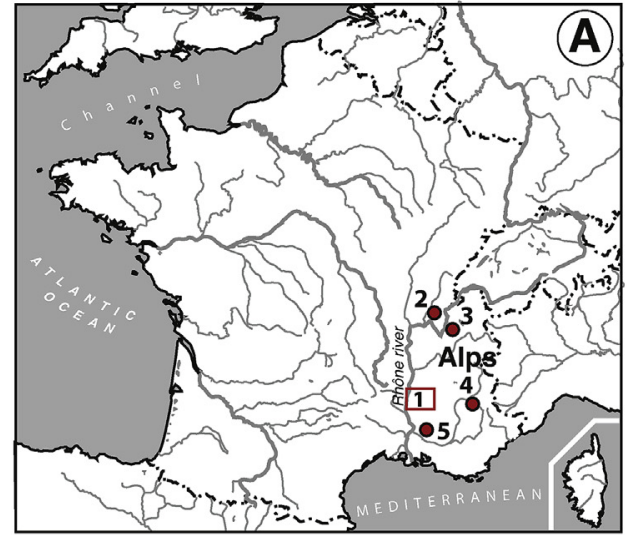

- South-Eastern palaeohydrological sites cited in texte

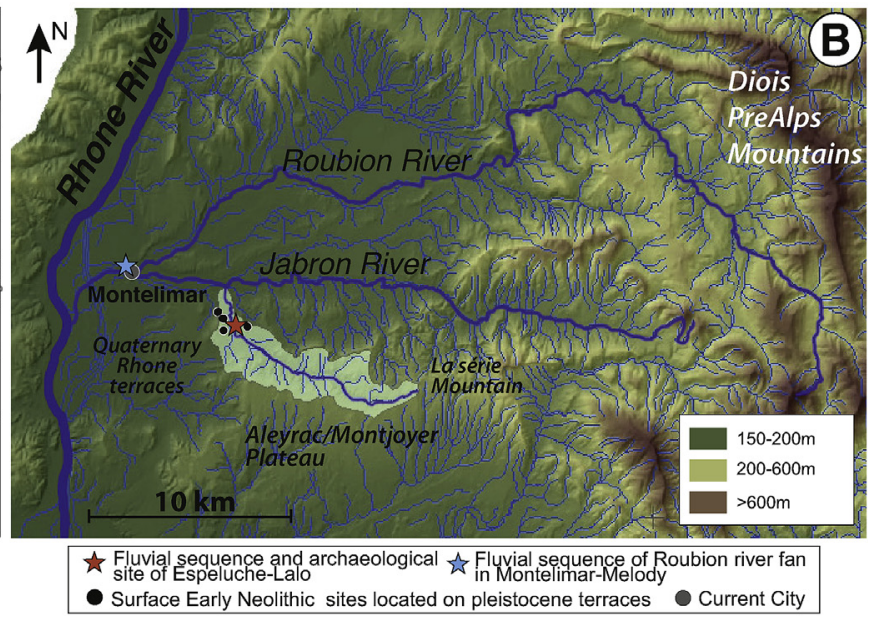

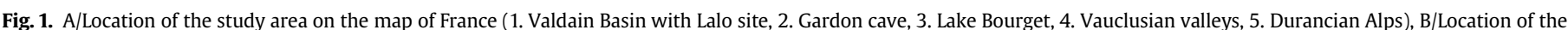

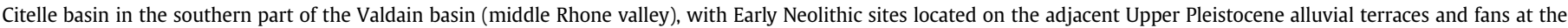
confluence between the Jabron and the Citelle rivers. The site of Lalo is buried in an early mid-Holocene terrace of the fan apex (GIS map by G.Davtian, Cepam).

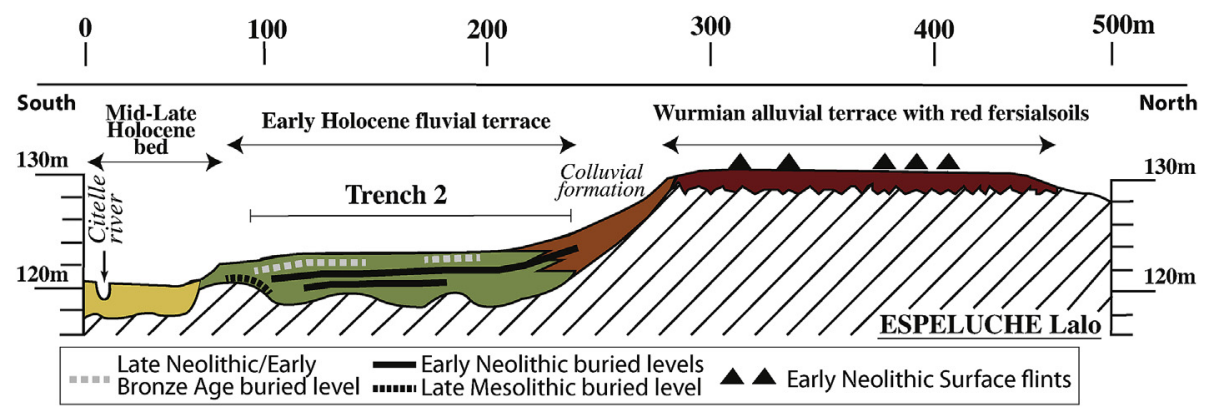

Fig. 2. Schematic transverse section of the floodplain of Lalo, showing the levels of the different terraces and the stratigraphical location of the archaeological levels.

\subsubsection{Archaeological data}

The Lalo excavation was carried out by digging several trenches $360 \mathrm{~m}$ long using mechanical means and by the clearing of a $5000 \mathrm{~m}^{2}$ surface in the context of a rescue excavation. It revealed an original occupation sequence, with very few equivalents in openair contexts for the entire south-east of France (Beeching, 2003; Guilbert et al., 2010). A Mesolithic Castelnovian layer and three successive Early Neolithic layers (Cardial-Epicardial) are clearly distinguishable within the thick alluvial sequence (Fig. 2).

The earliest Neolithic layer corresponds to a very early Cardial phase (between 7.55 and $7.39 \mathrm{ka}$, Table 1$)$. At this latitude $\left(44,5^{\circ} \mathrm{N}\right)$, it represents the most ancient settlements known so far of this culture, which is mainly recorded at sites in the karstic canyons of the Ardèche, the Cèze and the Gardon rivers and in shelters of the northern pre-Alps and the Bugey massif (Beeching, 2003). The two later levels can be attributed to the Epicardial culture on the basis of the archaeological material, which matches the ${ }^{14} \mathrm{C}$ datings at the end of the 8th millenium (Table 1). The fluvial evolution has truncated the occupation layers and the excavation brought to light only pits and post-holes, revealing two oval-shaped buildings: about $60 \mathrm{~m}^{2}$ in size, situated less than $20 \mathrm{~m}$ from one another. They are related to the second and third Epicardial layers, dated around 7.22-6.95 ka (Beeching, 2009). The lithic finds, although not very abundant, are similar to those from other sites in southern France (Guilbert et al., 2010) (fig. available in supplt data 1). Later occupation layers (final Neolithic Bell Beaker culture, Early Bronze Age) have also been identified, a few centimetres beneath the surface, within red colluvial formations emanating from the low
Pleistocene terraces.

\subsection{Materials and methods}

A systematic sampling of the principal pedosedimentary facies identified in the field was undertaken in the $140 \mathrm{~m}$-long alluvial cross section (Fig. 3). The sampling was vertical, following the stratigraphy, but also horizontal, in order to take into account the mobility of the river bed and the related pedo-sedimentary formations. A sample of about $10 \mathrm{~L}$ of bulk sediment was collected from the main levels and sieved at $500 \mu \mathrm{m}$ (samples e1 to e56, see Table 2, supplementary data). From this, we obtained charcoal and malacofauna remains and isolated the calcium carbonate rhizoliths on which measurements of the $\delta{ }^{13} \mathrm{C}$ and the $\delta^{18} \mathrm{O}$ have been carried out. Phytoliths were extracted from an aliquot of the same samples. The sediments have been shown to contain no preserved pollen signal.

\subsubsection{Chronology/stratigraphy}

More than 200 single stratigraphic units have been identified in the cross-section (especially in rhythmic filling of the channels), organized in 8 main pedo-sedimentary phases (Fig. 3), based on detailed stratigraphic studies, the organization and geometry of the fluvial deposits, and the available palaeopedological, archaeological and geochronological indicators (see below). The chronostratigraphy is based on 23 AMS radiocarbon dates determined from wood charcoal, after their botanical analysis (Fig. 3, Table 1). Six of these belong to more recent archaeological levels and are therefore 
Table 1

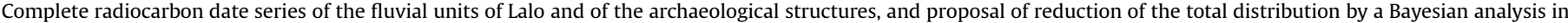
stratified series in OxCal software (Bronk Ramsey, 2005).

\begin{tabular}{|c|c|c|c|c|c|c|}
\hline Cultural period & Lab references & $\begin{array}{l}\text { Stratigraphic unit/Phase } \\
\text { number }\end{array}$ & Structure/contexte & $\begin{array}{l}\text { Uncaibrated } \\
\text { age }\end{array}$ & $\begin{array}{l}\text { Calibrated age with } 2 \sum \text { cal. } \\
\text { BP }\end{array}$ & $\begin{array}{l}\text { Oxcal } \\
\text { reduction }\end{array}$ \\
\hline & AA 39155 & US 179-5ae & Charcoal in Soil colluvia & $9294 \pm 69 \mathrm{BP}$ & $10680-10240$ & \\
\hline & AA 24898 & US 64b-5 & $\begin{array}{l}\text { Charcoal at the surface of the Black } \\
\text { Floodplain Soil }\end{array}$ & $7535 \pm 65 \mathrm{BP}$ & $8420-8170$ & $8410-8170$ \\
\hline & $\begin{array}{l}\text { LY-1518 (GRA- } \\
\text { 18665) }\end{array}$ & US 2-6 ab & Charcoal layer in channel filling & $7390 \pm 65 \mathrm{BP}$ & $8335-8044$ & \\
\hline \multirow[t]{4}{*}{ Late Mesolithic } & AA 32642 & Z1/6/G3-5-6a & Fire place & $7315 \pm 65 \mathrm{BP}$ & $8188-7935$ & $8210-7960$ \\
\hline & ETH 14840 & Diagnostic, phase-6b & Charcoal at the surface of a fluvisoil & $6930 \pm 70 \mathrm{BP}$ & $7940-7610$ & $7940-7680$ \\
\hline & AA 24896 & US $5-8 c$ & Charcoal in overflood silt & $6895 \pm 60 \mathrm{BP}$ & $7850-7610$ & $7800-7610$ \\
\hline & AA 24897 & US 42-9b & Charcoal layer in channel filling & $6705 \pm 60 \mathrm{BP}$ & $7670-7430$ & $7680-7510$ \\
\hline $\begin{array}{l}\text { Early Cardial/layer } \\
\quad 1\end{array}$ & AA 39156 & US $175-10$ & $\begin{array}{l}\text { Charcoal bed connected with a fire- } \\
\text { place } \\
\text { in Soil colluvia }\end{array}$ & $6662 \pm 61 \mathrm{BP}$ & $7649-7436$ & $7610-7460$ \\
\hline $\begin{array}{l}\text { Early Cardial/layer } \\
\quad 1\end{array}$ & AA 32641 & Str. 120-9d & Charcoals in Cardial ditch & $6585 \pm 60 \mathrm{BP}$ & $7590-7330$ & $7570-7420$ \\
\hline $\begin{array}{l}\text { Early Cardial/layer } \\
\quad 1\end{array}$ & AA 32638 & Str. 76-10 & Charcoals in Cardial ditch & $6560 \pm 65 \mathrm{BP}$ & $7580-7320$ & $7520-7320$ \\
\hline \multirow[t]{2}{*}{$\begin{array}{l}\text { Early Cardial/layer } \\
\quad 1\end{array}$} & AA 32639 & Str. $73-10$ & Charcoals in Cardial ditch & $6420 \pm 65 \mathrm{BP}$ & $7440-7210$ & $7430-7270$ \\
\hline & AA 39154 & US $12 b-13 d$ & Charcoals in overflood sandy-silt & $6373 \pm 57 \mathrm{BP}$ & $7430-7200$ & $7410-7200$ \\
\hline Epicardial/layer 3 & AA 32644 & Str.8-17 & Charcoal of a Fire place & $6220 \pm 60 \mathrm{BP}$ & $7270-6940$ & $7270-7010$ \\
\hline Epicardial/layer 2 & $\begin{array}{l}\text { GifA } 40303 \text { (SAC- } \\
1196)\end{array}$ & Z1/str.14 & Charcoal in Epicardial ditch & $6200 \pm 60 \mathrm{BP}$ & $7246-6995$ & \\
\hline Epicardial/layer 3 & LY-11187 & Str.62 (C) & Charcoal in Epicardial Ditch & $6190 \pm 30 \mathrm{BP}$ & $7176-6989$ & $7209-7010$ \\
\hline Epicardial/layer 3 & Ly 11186 & Str.62 (B) & Charcoal in Epicardial Ditch & $5955 \pm 60 \mathrm{BP}$ & $6938-6662$ & \\
\hline MidNeolithic? & AA 32643 & & Charcoal in Neolithic ditch & $4940 \pm 55 \mathrm{BP}$ & $5890-5580$ & \\
\hline Early Bronze Age & AA 32645 & Str. 34-18 & Charcoal in Early Bronze Age ditch & $3505 \pm 60 \mathrm{BP}$ & $3919-3629$ & \\
\hline Early Bronze Age & $\begin{array}{l}\text { Lyon-1951 (Poz- } \\
\text { 1571) }\end{array}$ & Str. 55-H4 & Charcoal in Early Bronze Age ditch & $3560 \pm 50 \mathrm{BP}$ & $3979-3695$ & \\
\hline Early Bronze Age & ARC 1465 & 18 & Charcoal in Early Bronze Age ditch & $3476 \pm 76 \mathrm{BP}$ & $3980-3565$ & \\
\hline Early Bronze Age & ARC 1467 & Str.1-18 & Charcoal in Early Bronze Age ditch & $3423 \pm 64 \mathrm{BP}$ & $3870-3485$ & \\
\hline Late Bronze Age & AA 24899 & 19 & Charcoals in Soil colluvia & $2930 \pm 50 \mathrm{BP}$ & $3260-2910$ & \\
\hline
\end{tabular}

not appropriate to this study. 15 dates come from archaeological structures and 8 from pedosedimentary formations. The span of the calibrated dates was reduced by processing the stratified radiocarbon dates in a series (Oxcal program, Bronk-Ramsey, 2005). The chronological accuracy of the data varies according to the position in the stratigraphic sequence, the sedimentation speed and the sampling grid. For the charts, we have taken into account the midpoint of the total span (95\% confidence after oxcal reduction) of each calibrated date. The interval between two dates is plurisecular to secular, between 8.5 and $7.8 \mathrm{ka}$. Later, it strongly decreases to $7 \mathrm{ka}$ (2-4 dates/centuries), in relation to acceleration of the sedimentation rates and geomorphological changes. Based on these elements, palaeoenvironmental diagrams are presented according to a segmented age model.

\subsubsection{Palaeohydrology: reconstitution through fluvial geomorphology and sedimentology}

Detailed examination of the morphology (in particular the width/depth ratio) of the ancient channels and of the nature (grain size) of the sediments provides information on the hydrological processes within the hydrosystem (Schumm, 1977; Bravard et al., 1997). Braided channels are narrow and not particularly deep, with high width/depth ratio, while meandering watercourses present low width/depth ratio (Richard, 1982). For this purpose, we simultaneously studied the stratigraphy of (1) the channel fill, (2) the overbank deposits and (3) the flood bed (flood deposits) (Fig. 3, fig. supplt data 2).

The lithofacies assemblage provides information on the flow conditions (ratio solid/liquid load) which are the main control variables on the scale of the basin. Measurements of maximal grain size and the coarse/fine fraction ratio were based on analyses by thin section of fine and medium sedimentary fractions. In the coarse gravel-pebble fraction, counts were made on 50 elements. The analysis of the sources of alluvial aggradation, mainly through petrography, completes the study (Fig. 4I/L). The presence of glaucony indicates that the erosion source was in the middle and upper catchment area (Albian-Aptian and Turonian horizons) (Fig. 4I). Clay soil aggregates and ferromanganese oxide nodules indicate the erosion of leached red/brown soils from the Quaternary lower terraces (Fig. 4K) and rounded tufa fragments indicate the destruction and erosion of travertine formations upstream (Fig. 4I). Magnetic susceptibility was measured directly on the bulk samples with a Bartington MS2E sensor to discriminate sedimentary sources and pedogenic development: low values for geological marly and calcareous formations and high values for fersiallitic soil aggregates and for authigenic concentrations formed through oxydation and bacterial processes during floodplain soil formation in situ (Dearing, 1999). Two measurements were averaged (in $\left.10^{-6} \mathrm{~m}^{3} / \mathrm{kg}\right)$.

\subsubsection{Palaeopedology (micromorphology) and isotopic} geochemistry of the secondary $\mathrm{CaCO} 3$

The identification and classification of pedological features was carried out by examination of 40 thin sections hardened with a transparent epoxy resin under a petrographic microscope (in parallel and polarized light), at different magnification levels (10x to 200x) (see Table 2). Comparision with pedological features that are currently evolving in known climatic, anthropic and biological conditions enables the reconstruction of the palaeoenvironmental conditions of their development (Courty, 1994; Cremaschi and 


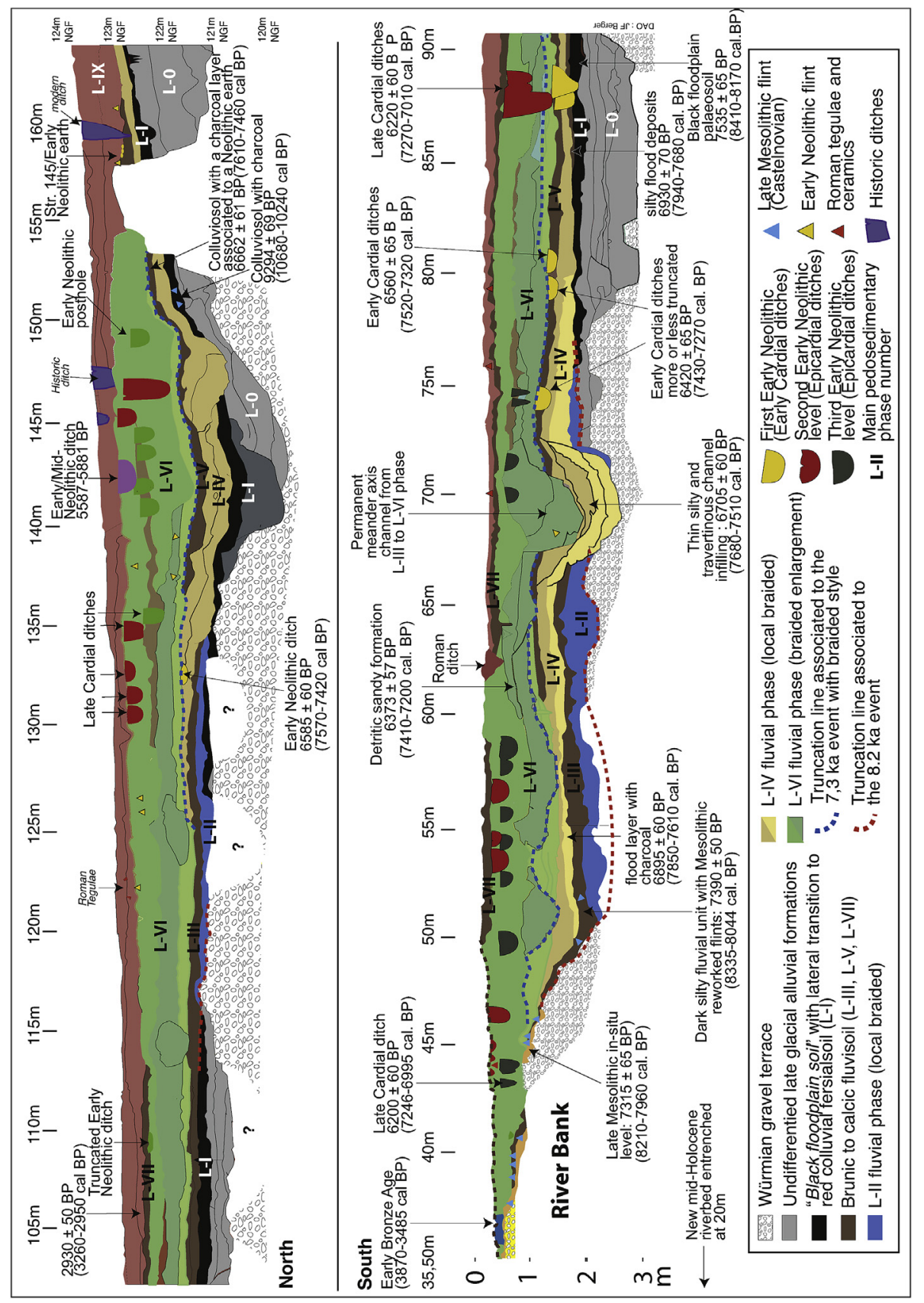

Fig. 3. Transverse section (T2) across the Citelle river floodplain showing the main pedosedimentary units, the archaeological structures and the ${ }^{14} \mathrm{C}$ dates.

Nicosia, 2012). The degree of maturation and of weathering of fluviosoils is identifiable by the degree of organization of soil matrix, by features related to biological activity, by analysis of organomineral complexes present, by the spatial and hierarchical organization of the various components and by the degree of dissolution of soil calcite grains. A high rate of bioturbation and pedoturbation leads to an excremental organization of parent material, and to a micro-aggregation of soil matrix which appears as small plurimillimetric aggregations with granular to micropolyhedral morphologies (Fig. 4A/E). The calcite biospheroids produced by earthworm activity, known to accumulate especially in the uppermost part of the soil (Canti, 2003), can also be concentrated in fluvial units where they are observed in wellsorted sand bed units, reflecting the reworking of soil litters. We used a visual chart (Bullock et al., 1985) to measure grain size and propose a semi-quantitative petrographic analysis. The use of incident light helps to differentiate the carbonized plant fragments (micro-charcoal) from more or less evolved soil organic matter and from the opaque sesquioxides in order to estimate the charcoal quantities in the soils and the alluvia. Micro-charcoal was quantified by a method of image analysis (Aphelion program, OMEAA database, Berger, Barra and Lejot, Lyon 2 University) in order to obtain the areal percentage and absolute particle number.

Fossil pedological carbonates from the soils and the alluvia have been studied separately due to their importance as indicators of the pedoclimatic features and plant density (pseudomycelia, rhizoconcretions, nodules). Using the fractionation factor determined by Romanek et al. (1992), the carbon isotopic composition of soil $\mathrm{CO}_{2}$ can be calculated from the carbon isotopic composition of pedogenic carbonates. In the floodplain, this material is produced along 

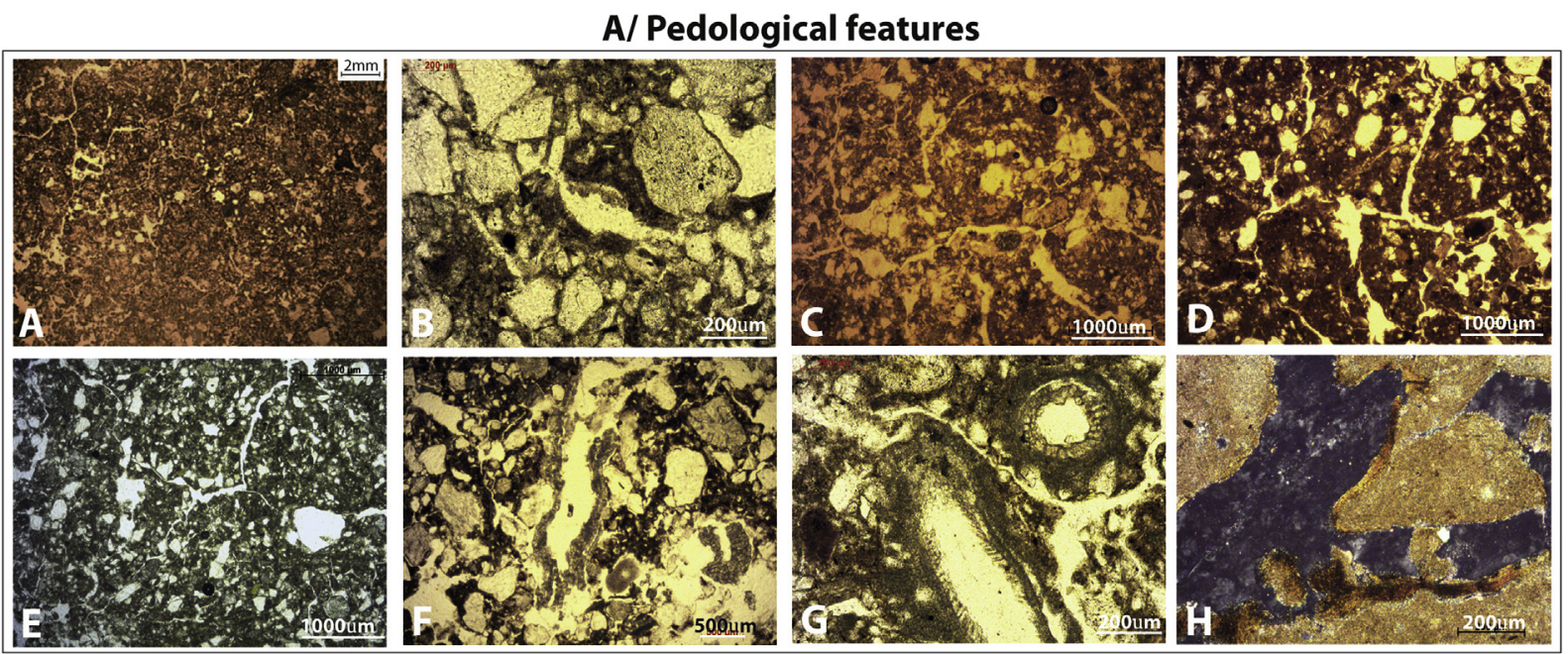

\section{B/ Sedimentary sources}
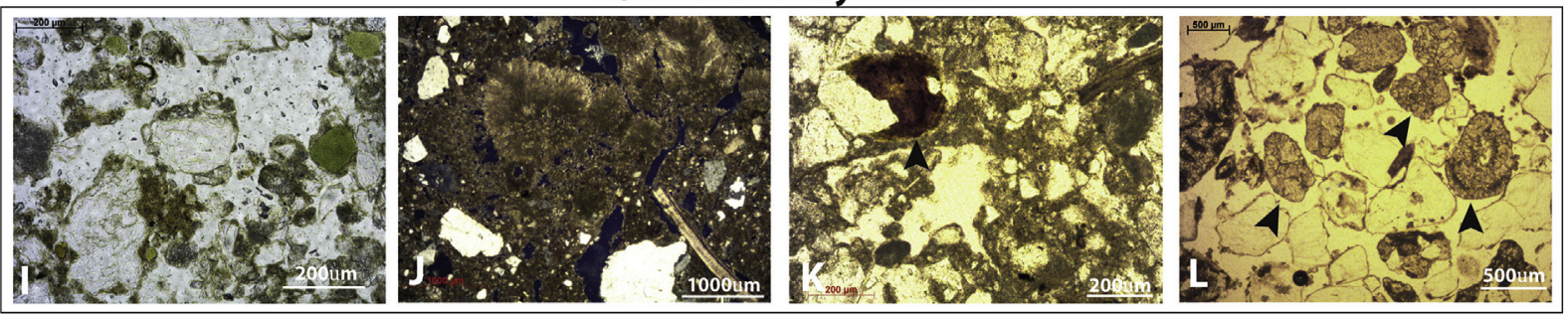

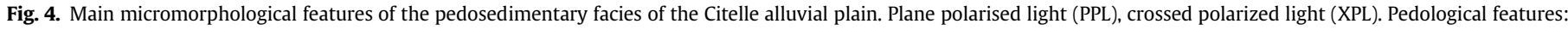

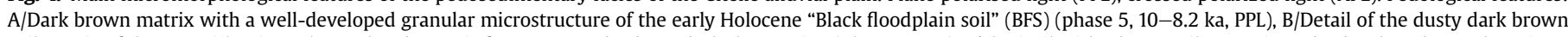

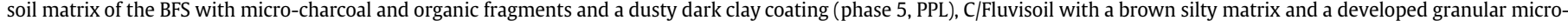

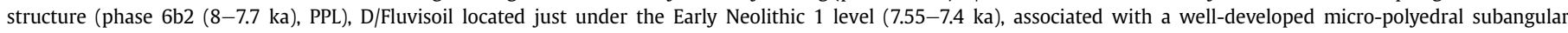

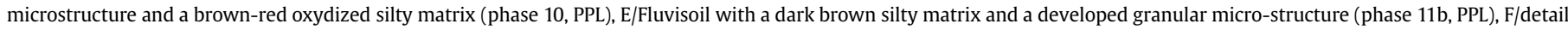

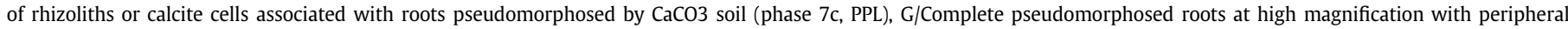

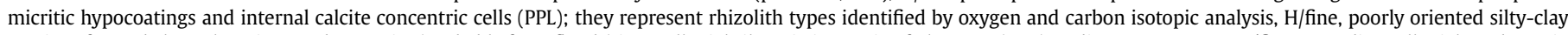

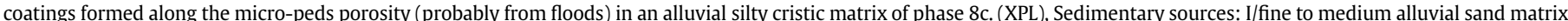

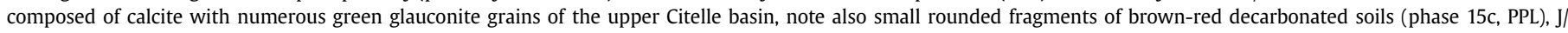

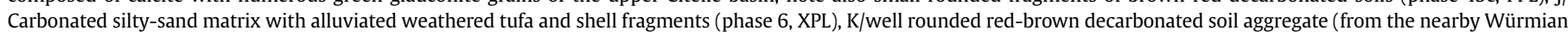

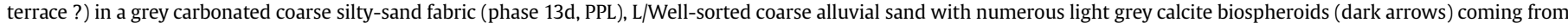
adjacent fluvial soil litters (phase 8d, PPL). (For interpretation of the references to colour in this figure legend, the reader is referred to the web version of this article.)

the root network of the local vegetation. The M.E.B. analysis of these bio-indicators identified plant structures which tend to confirm this hypothesis (Bonté, 2006). Evapotranspiration is the major process that generates secondary carbonates, thus the $\delta^{18} \mathrm{O}$ and the $\delta^{13} \mathrm{C}$ of the pedological carbonate nodules indicate that of rainfalls (Cerling, 1984). Evaporation causes the enrichment not only of the $\delta^{18} \mathrm{O}$ but of the $\delta^{13} \mathrm{C}$ as well (Salomons et al., 1978). The $\mathrm{CO}_{2}$ degassing increases the amount of heavy carbon isotopes in soil carbonates compared to that of water (Salomons et al., 1978). A pyrolysis at $350{ }^{\circ} \mathrm{C}$ of carbonate nodules was performed to remove organic residues, potential sources of carbon signal contamination. Repeated analyses performed on the centre and the periphery of the same sample demonstrated that the risk of an alteration of the isotopic signal by diagenetic phenomena (dissolution/re-precipitation) is low (Bonté, 2006). Similarly, the analysis of different sizes of samples revealed a minimal enrichment of $\delta^{18} \mathrm{O}(4 \%)$ and a slight depletion of $\delta^{13} \mathrm{C}(2.5 \%)$.

\subsubsection{Palaeoecological reconstitution}

1.2.4.1. Analyses of charcoal and phytoliths. Wood charcoal and phytoliths have been used as proxies for vegetation. Phytoliths and macroscopic wood charcoal mainly reflect the local vegetation when they are recovered from buried soils, and the vegetation of the catchment area when they are recovered from colluvial or alluvial layers (Delhon, 2005). Charcoal fragments from archaeological structures are recovered by sieving with 5 and $2 \mathrm{~mm}$ meshes and at $500 \mu \mathrm{m}$ when they come from natural sedimentary deposits. In archaeological structures (eroded pits and hearths from the Mesolithic to the Bronze Age), charcoal is the vestige of wood fuel gathered by the site occupiers in the surroundings. Outside of these structures, in natural intercalated levels, it is the results of vegetation fire.

Due to the sampling context, in a pedosedimentary trench, charcoal assemblages are often small, especially those that are not from archaeological structures and the information is mainly qualitative (Fig. 5). It has been possible to show that these charcoal assemblages are palaeoecologically reliable, despite their being small, thanks to the numerous samples analysed in several sequences of the middle Rhone valley (Delhon, 2005; Delhon and Thiébault, 2008). Complete charcoal data are available on Table 3 in supplement data.

Phytoliths (microscopic opal particles from plant cells or tissues) were chemically extracted from the sediment. The samples proved to be very rich, and a minimum of 200 phytoliths have been identified for each assemblage. Several morphotypes were identified, classified in three groups: Poaceae (Twiss et al., 1969), dicotyledons (Piperno, 1998), and cf. pine (Delhon et al., 2003). We attributed the latter to pine on the basis of its abundance in reference samples from a pine forest soil, but it subsequently proved to be also produced in small amounts by broadleaved trees (Delhon 


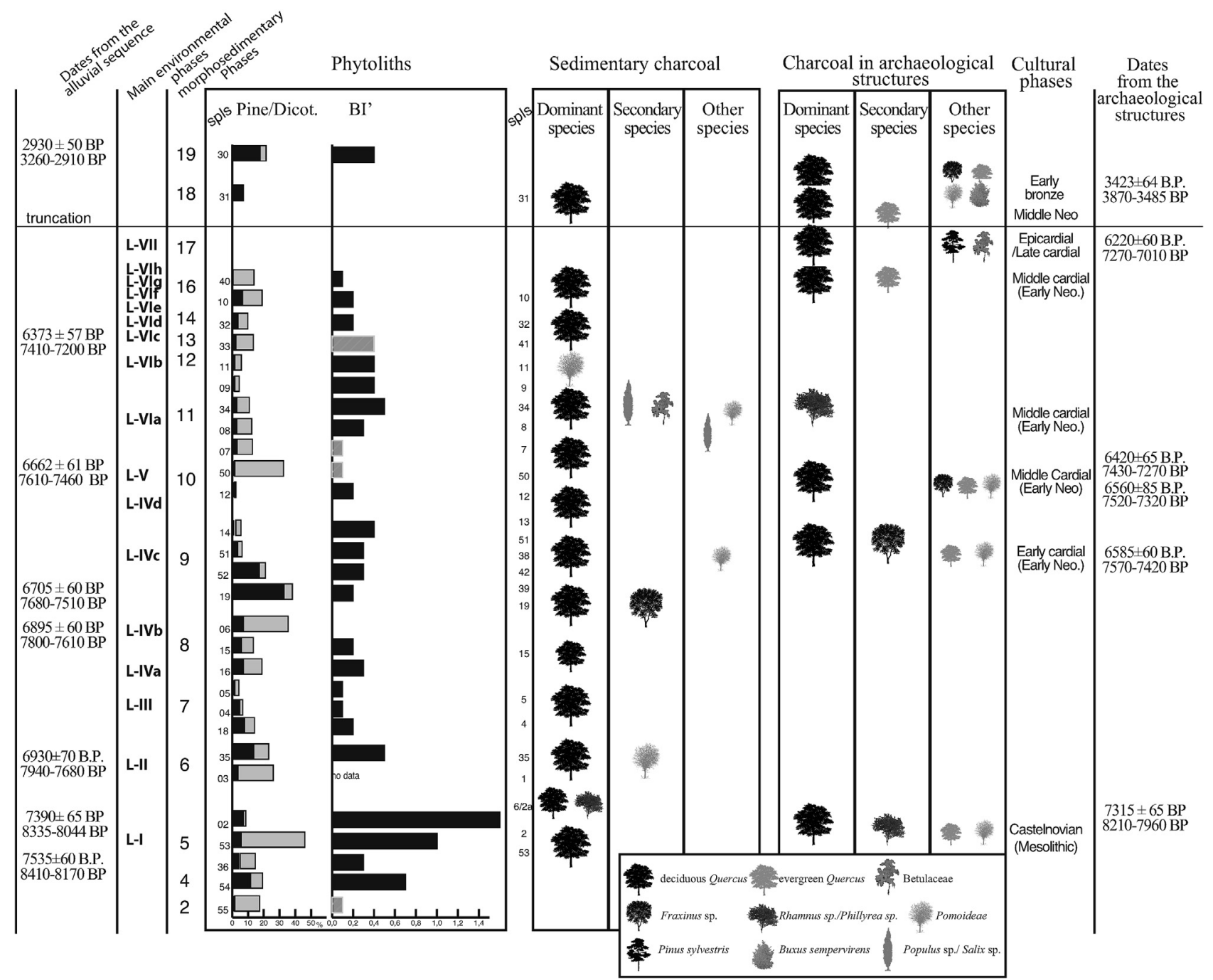

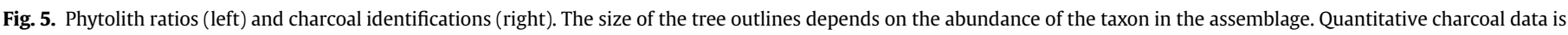
available in Table 3.

et al., 2010), so its abundance must be interpreted cautiously. The relative proportions of these three groups are used to estimate the density of the woody vegetation (indicated by dicotyledons and pine morphotypes) versus grasses (indicated by Poaceae morphotypes). As Poaceae produce larger amounts of phytoliths than any other taxon, every increase, even slight, of tree phytoliths can be of high interest. The production of some morphotypes by grasses is linked to environmental factors, especially the bulliform cells (evapotranspiration). Several evapotranspiration indexes have been proposed based on the relative proportion of bulliform cells vs. other grass morphotypes (Delhon, 2005, 2007; Brémond et al., 2005; Strömberg et al., 2007; Messager et al., 2010). We used at Lalo the Bulliform Index' (BI') that takes into account the presence of some doubtful eroded forms (Delhon, 2005, 2007).

1.2.4.2. Malacofauna study. Sampling was carried out for analyses of mollusks from a variety of soils and sediments representative of the different pedosedimentary environments along the trench section (correspondence between samples numbers and main environmental phases are specified in the Table 2). Thirty samples of about $10 \mathrm{~L}$ were analysed in the usual way (Evans, 1972; Puisségur, 1976). The molluscan assemblages have been plotted either as percentage frequency or absolute value histograms. Rare taxa are indicated by single plus. The nomenclature is that of
Welter-Shultes (2012).

\section{Results}

\subsection{Fluvial palaeodynamic}

In this paper we focus on sedimentary subphases 5 to 17, which provide particularly good evidence and date to between 8.5 and 7 ka (Table 2). These 13 morphosedimentary and palaeoenvironmental oscillations are grouped in 7 main phases, 3 active (Lalo II, IV, VI) and 4 stable (Lalo I, III, V and VII) (Fig. 3, Table 2) that structure the multi-proxy data presentation. During the Middle Holocene, the proportion of fine, cohesive sediments in the silty overbanks of palaeo-riverbeds of the Citelle limited local contribution from erosion and undercutting. The fluvial style of the Citelle river oscillates between meandering phases, with a more or less entrenched river bed, associated with the creation of more or less marked alluvial levees, and phases of transition towards a braided style, towards the formation of numerous shallow channels covering an area that extends over all the investigated plain (about $140 \mathrm{~m}$ ) (Fig. 3). Certain intermediary phases have been identified as well: they show progressive transitions from one state of the fluvial system to another (wandering channel types). Anastomosis is also potentially attested. 


\subsection{Soils, calcium carbonates, isotopes}

Our observations show that under present climatic and environmental conditions (pluviometry $>800 \mathrm{~mm} /$ year, average $\mathrm{T}^{\circ}$ $13{ }^{\circ} \mathrm{C}$ year), no secondary carbonate formations are found in the soils of the middle Rhone valley (Bonté, 2006). They begin to be detected in the north of Catalonia and in certain more arid regions of calcareous Provence with high water deficit and summer dryness (pluviometry $<600 \mathrm{~mm}$, average $\mathrm{T}^{\circ} 14^{\circ} \mathrm{C}$ year). The Holocene soil archives of the MRV indicate concentrations of rhizoliths during dryer periods (Berger and Brochier, 2000, Berger, 2006) (Fig. 4F/G). Their isotopic composition depends on the environmental conditions and the origin of the rains that prevailed at the time of their formation (Bonté, 2006).

The current mean isotopic values obtained in the water of rivers of the Valdain basin, a supra-Mediterranean region, indicate a relative depletion of oxygen $18(-6 \%)$ and an enrichment in carbon $13(-8.89 \%)$ in a reforested basin. The mean annual $\delta^{18} \mathrm{O}$ of precipitation decreases systematically across Europe with increasing distance from the northern Atlantic Ocean (Rozanski et al., 1993). In the middle Rhone valley, changes in the $\delta^{18} \mathrm{O}$ of the oceanic source region of precipitation appear to cause the main variations during the Holocene of the rhizoliths $\delta^{18} \mathrm{O}$. Low values indicate Mediterranean rains and high values indicate North Atlantic rains (Bonté, 2006) (Fig. 7B).

The isotopic analysis of current fluvial soils water shows that the presence of a dense river forest is associated with values of $\delta^{13} \mathrm{C}$ ranging from -8 to $-9.4 \%$ (Bonté, 2006). As the $\delta^{13} \mathrm{C}$ of the carbonates reflects the signal of soil gas produced by the stational vegetation (Cerling and Quade, 1993), the repeated depletions observed on the isotopic curve show local pertubations in forest cover associated with the development of grassland or shrubby vegetation. Although the entire period is generally associated with dense canopy (values between -8 et $-10 \%$ ), 4 peaks showing important vegetation changes have been distinguished on the basis of $\delta^{13} \mathrm{C}$ isotopic values, with extreme values of between 0 and $+1.5 \%$ (noticed $1-2,3,5$ and 8 in Fig. 7B). Three less important peaks are observed with values of -6 to $-7 \%$ o $(4,6$ and 7 in Fig. 7B). With the exception of peak $n^{\circ} 8$, each increase of $\delta^{13} \mathrm{C}$ corresponds to an episode of increase in micro-charcoal. These changes could be linked to alterations by fire of the vegetation of the basin and the Citelle floodplain (Fig. 7B). The first 3 peaks (between 8.2 and $8.1 \mathrm{ka}$ and around $7.8 \mathrm{ka}$ ) do not appear to be associated with the presence of human communities on the site. This is not the case for the following peaks (4, 5, 6 and 8) chronologically associated with the Cardial/Epicardial settlement in the floodplain (see EN1 and 2 in Fig. 7B).

In the Lalo sediment, $\delta^{18} \mathrm{O}$ varies from -3.2 to $-7 \%$, around a mean value of about $-6 \%$. We interpreted these rather low $\delta^{18} \mathrm{O}$ values as reflecting relatively wet conditions. Only 4 increases of $\delta^{18} \mathrm{O}$ values are noted at $8.2-8,7.8,7.55$ and $7.25 \mathrm{ka}$. The first (6a1/ $6 \mathrm{a} 2$ ) is the longest ( 4 measurements spread over 2 centuries) and records a long-term tendency, while the others correspond to specific measurements. These signatures could represent warmer periods favouring evapotranspiration or climatic events influenced by air masses and precipitation from the Mediterraean. The clear correspondence of these $\delta^{18} \mathrm{O}$ enrichment phases with high $\delta^{13} \mathrm{C}$ values that reveal more open landscapes and micro-charcoal peaks linked with fire (Fig. 7B) indicates a stronger influence of dry Mediterranean atmospheric circulation in southern France.

\subsection{Malacological evidence}

The oldest (samples e56, e55, e54) and most recent (e30) assemblages must be viewed with caution because of the small number of shells collected. Otherwise, the number of shells in the samples ranges between 54 for the poorest and 3232 for the richest. The entire malacofauna recovered is composed of 10984 individuals belonging to 61 taxa, 12 of which are freshwater taxa.

In terms of specific composition, the malacological assemblages are quite monotonous. The stratigraphical distribution of nearly all the species extends through the whole sequence. Even reputed synanthropic and xerophile species such as Cernuella spp. and Oxychilus hydatinus seems to occur in the early phases (intrusion by bioturbation). This homogeneity of data precludes any attempt to divide the molluscan series into biozones based on the mere occurrence of taxa. The malacofauna is dominated by a rather small number of species or groups of species.

Species of dry, open country have low percentage frequencies throughout the sequence. Observation of both the relative (Fig. 6A) and absolute values shows that they are only significant in the most recent phases, from e34 towards the top of the sequence.

Woodland species have a sizable presence throughout the series. A distinction can be made between Pomatias elegans (the most abundant land snail in the sequence), an "intermediate" species that burrows in loose crumbly soils and feeds on dead leaves in fairly open woodlands or even srub vegetation, and species that need shade and humidity such as Discus rotundatus, Aegopinella nitidula, Acanthinula aculeata and some Clausiliidae (the two later being more "exclusive" woodland taxa). We observe (Fig. 6A and B) the continuous and relatively high number of $P$. elegans in the sequence, with outstanding peaks in e3 (SP 6b2), e6 (SP 9b2), e7 (SP 11a) and e10 (SP 13ac). The shade-demanding $D$. rotundatus shows several significant peaks in e14-e13 (SP 9b2), in e50 (SP10), and between e11 and e32 (SP12 to SP14), the latter being supported by a concomitant increasing of $A$. nitidula and A. aculeata (Fig. 6A). A maximum of woodland vegetation seems to occur during these relative peaks of $P$. elegans associated with shade-loving species, while absolute data and histograms provide a further insight into these changes (Fig. 6B). For example, shade-demanding snails such as $D$. rotundatus, $A$. nitidula and $A$. aculeata are well represented in subphases $12 \mathrm{ab}, 13 \mathrm{ac}$ and 14ac. This would indicate an increase of fairly mature wood stands towards subphase 13, when Cardial occupations temporarily disappeared from the floodplains (Fig. 5), followed by a moderate decrease of the wooded surface after phase 14. Despite some importance of woodland snails, malacofauna that frequents humid, open ground - from damp meadows to riparian marshes - is dominant (Fig. 6C). Snails of damp meadows and woodland snails present opposing curves: woodland clearance favours damp, open environments rather than dry, open environments (clear link with floodplain evolution).

The malacofauna of marshes and meadows tend to fluctuate in the same way (Fig. 6A and C). Four peaks are distinguishable, centred upon subphases 6 (e35), 9b1 (e19), 9eg-10 (e43-e38) and 11b (e9). Marsh malacofauna includes amphibious freshwater snails and a snail typical of environments in which waters are drying up. Except for peaks e9 (SP 11b)-e38 (SP 9eg) (channel filling), all characterize local floodplain environments.

Freshwater molluscs living in slow-moving or still permanent waters occur throughout the sequence (in low numbers), but present a maximum in $8 b c / 9 b 1,9 b 2$, and secondarily in $6 b 2 / 7 b$. The species considered characterise clear, standing or slowly moving waters, rich in aquatic vegetation (palaeochannels here). They reflect periods of a more or less permanent flow of the Citelle.

In conclusion:

- The three assemblages (subphases 2 and 4), very poor in individuals, are not reliable, although compatible with a LateGlacial climate and environment. 

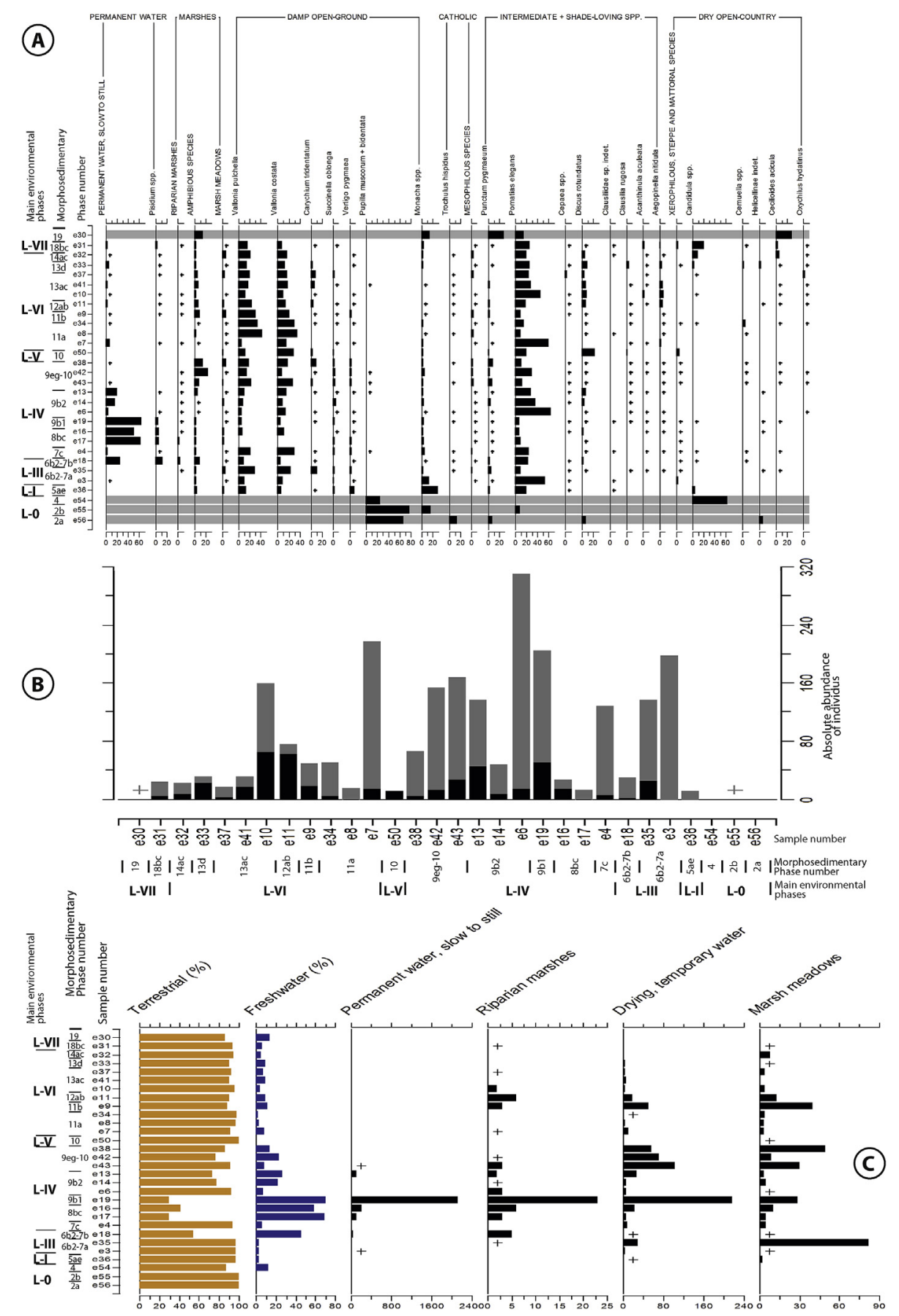

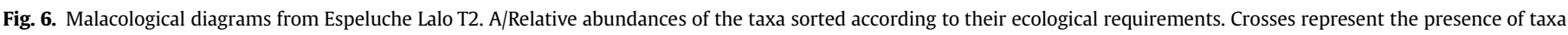

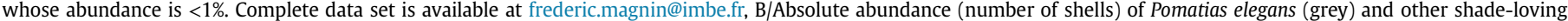

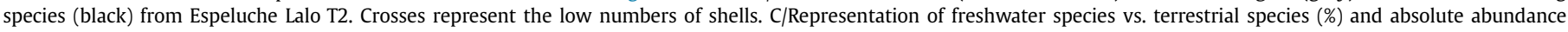
(number of shells) of aquatic and marsh ecological groups. Crosses represent the presence of groups in samples yielding low numbers of shells.

- From the end of subphase 13 to the top of the sequence, dry open-ground species develop, but their numbers are low, this kind of habitat being still restricted.

- Inbetween, the malacofauna does not display any clear marked succession. The heterogeneous landscape seems to remain a mosaic of open woods and moist or damp meadows, these tesserae experiencing some slight fluctuations. However, moist and damp meadows are always markedly dominant whereas wood stands persist throughout the sequence. Some more marshy habitats and even permanent water bodies may occur. They could have in some cases only a local significance.
2.4. Integrated multi-proxy analysis of pedosedimentary and ecological evolution in the Citelle river floodplain during the midHolocene

The base units (Lalo 0) were deposited over an older and poorly dated sequence, probably formed between the Late Glacial and the beginning of the Holocene (Preboreal). This first coarse alluvial unit, is topped by several phases with multiple interlocked channels covered by colluvial post-glacial formations at the foot of the upper terrace, dated to $10.64-10.28 \mathrm{ka}$ (Fig. 3). The malacological analysis (Figs. $6 \mathrm{~A}$ and $2 \mathrm{~A}-4$ ) shows that all 3 assemblages share 

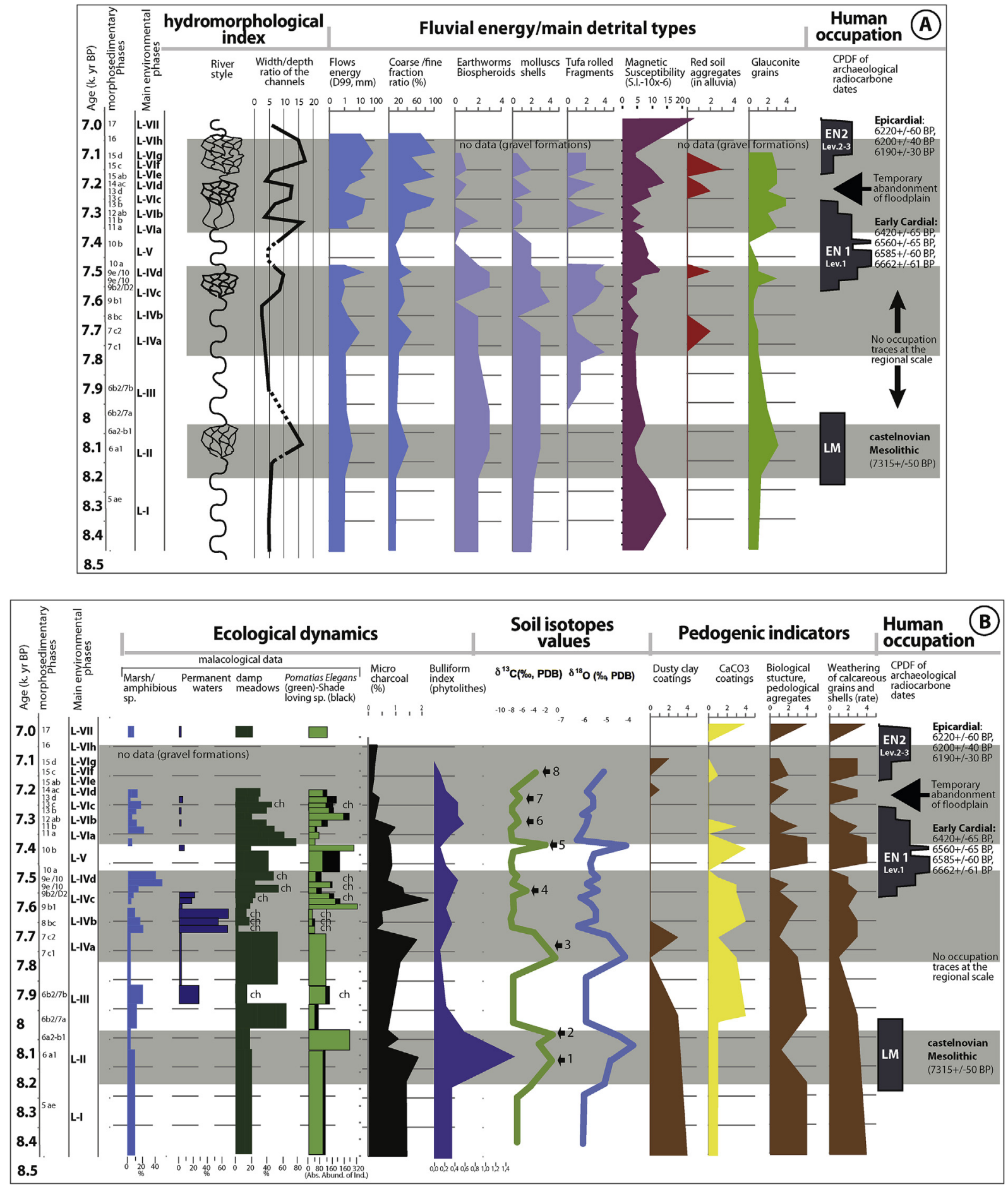

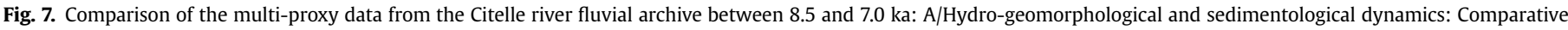

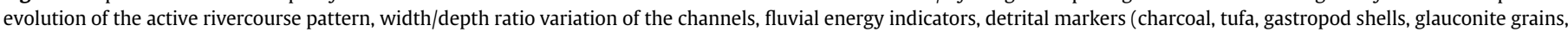

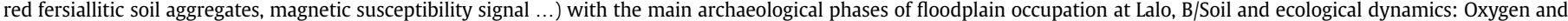

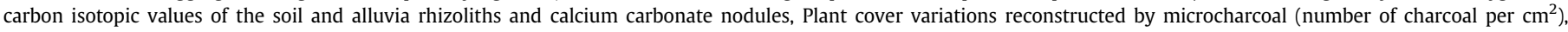

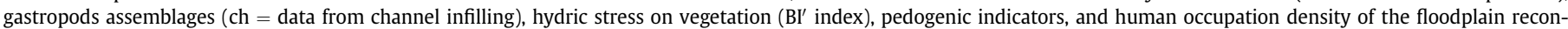

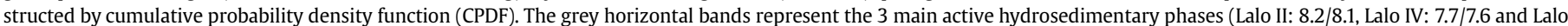
VI: 7.35/7.1 ka).

characteristics indicative of cold steppe conditions which confirm the relative dating.

Lalo I (SP 5a-e): the entire plain is characterized by morphopedological stability (10.5 and $8.2 \mathrm{ka}$ ). A black soil (10 YR 2/2) was formed at the expense of the Late Glacial alluvia when the Citelle river bed was deeply entrenched in the northern part of the plain up to the foot of the Late Glacial formations (Fig. 3L-I). It presents low hydro-sedimentary activity (with predominantly 
silty-travertine infills). The degree of soil weathering is high, with indications of leaching, but the decarbonation is not complete (Fig. 4B, Table.2). The advanced aggregation, the strong porosity and the presence of goethite coatings indicate good draining conditions that allowed some oxidation to develop during the pedogenesis. The high proportion of micro-charcoal in the soil matrix along with humified plant micro-debris (Figs. 4B and 5) explains its very dark colour and indicates that the vegetation cover was subject to fires. Multi-proxy data indicate a landscape comprised of a mosaic of vegetation or successive stages of vegetation, created by frequent fires (a cumulating effect over two millennia of soil development). Data reveal a trees/open forest indicated by phytoliths, charcoal and malacological assemblages with a grassland cover (Figs. 5, 6A and 7B). This vegetation structure is confirmed by the median value of the $\delta^{13} \mathrm{C}$ (Fig. 7B).

Lalo II (SP 6a-b1): Around 8.2-8.05 ka, the stability of the floodplain ends, with a cutoff of the northern channel of the river, which shifts its course southwards, to the foot of the Würmian terrace outcrop on which a Mesolithic settlement had been established earlier. The wider and more undulating channel morphology reveals an abrupt instability phase (Fig. 3). The energy of the river increases considerably and results in a rapidly-formed aggradation that is fine and sandy (Fig. 7A). The E/H black soil (Lalo I) is strongly truncated, as are the exposed banks of the Mesolithic site which are also eroded by a gully network due to concentrated rains, before its final covering by alluvia. The detrital alluvial markers reveal the leaching of pedological litter upstream and an active erosion of Albian-Aptian sandy marl formations (Figs. 7A and 8). Macrocharcoal in the alluvia provides evidence for the occurrence of Rhamnus alaternus/Phillyrea sp., although deciduous Quercus remains dominant. Charcoal assemblages from the Mesolithic structures are characterized by a small amount of evergreen taxa, interpreted to be an occasional and local Mesolithic impact on the vegetation (Delhon and Thiébault, 2009). The abundance of microcharcoal provides evidence for fires $(>1.5 \%)$, recorded in 2 peaks of activity separated by a strong intermediary decrease (Figs. 7B and 8). Fire events contributed to the rise of erosion in the upper ba$\sin$. Simultaneous low $\delta^{18} \mathrm{O}$ and $\delta^{13} \mathrm{C}$ values reveal a major change in vegetation structure (open) and in rain origin (probably mediterranean) (Fig. 7B). The phytolith bulliform index (BI') is also very high and could corresponds to an increase of evapotranspiration and of seasonality, as has been identified a few kilometres away at Mondragon - Les Brassières (Delhon, 2007).

Lalo III (SP 6b2-7b): Around 8.07-7.95 ka, the river was quite deeply incised on $\mathrm{m} 70$ of trench 2 and resumed a meandering style with a fine alluvial infill (silts and travertines), characterizing a long fluvial stability. A dark grey fluvisol (2.5Y 3/2) indicates the simultaneous stability of the floodplain up to 7.80-7.75 ka. Granular micro-structure, the weathering of limestone grain and a concentration of secondary carbonates (nodules and hypocoatings) (Table 2, Figs. 4D and 7B) indicate soil evolution and high evapotranspiration. High alluvial energy flows and detritism are minimal (Fig. 7A). In the generally moister environment, fire activity decreased (micro-charcoal: $0.6-0.8 \%$ ). When fire was active, it mainly affected the deciduous predominant oak forest (Fig. 5). An increase in pine phytoliths perhaps indicates pine species on slopes. The malacological analysis shows an abundance of species of damp meadows and open woodland ( $P$. elegans), which indicates an extension of humid areas and riparian forest in the floodplain (Figs. 6B and 7B).

Lalo IV (SP 7c1-9e): A new period of hydro-sedimentary imbalance began around 7.75-7.70 ka. Fluvial signatures and multi-proxy data divide this geomorphically unstable period into 4 sub-phases (IVa-d) (Fig. 7A, Table.2). The Citelle river first built up a sandy overbank deposit (average of $3 / 4 \mathrm{~mm} /$ year). Travertine formations were destroyed and reworked in the alluvia. Repeated high-energy floods interposed thin layers of gravel on the overbanks of the levee. A strong increase in fire activity (micro-charcoal: $1.2-1.7 \%$ ) reduced the basin's plant cover and amplified the erosion signatures. Lixiviation traces and laminated, clayey, poorly oriented coatings, due to the increase of flood magnitude appear in sediment (Figs. 4H and 7A). Rhizoliths decreased strongly during this episode (weak evapo-transpiration). The presence of small aggregates of red fersiallitic soils implies the erosion of Quaternary terraces (Figs. 4K and 7A).

A short phase of incision/sedimentation of the Citelle river (Lalo IVb, SP 8b/c) interrupted this aggradation episode. This phase could have been the result of rapid post-fire plant recolonization, within a more humid context. The forest became denser again, as shown by the increase in tree phytoliths (Fig. 5). The alluvia indicate a phase of moderate hydraulicity in the active channel (sand and fine gravels), with a decrease of detrital markers (Fig. 8, Table.2). The aquatic malacofauna indicates the regular presence of water in the channels (Fig. 7B). Aggradation began again during phase Lalo IVc (SP 8d/9b1-9d2, 7.60-7.47 ka). The channel morphology became wider and more shallow, with heterogeneous flows, interspersed by alternating fine gravelly sand and greyish silty deposits. The levee rose quickly (average of $3 \mathrm{~mm} /$ year). This increasing erosion associating all detrital markers (Fig. 7A and B) corresponds to fire events $(1.25-2.1 \%)(7 \mathrm{~b}, 8)$, followed by forest soil litters erosion (mollusc shells from open woodland, shade-loving species (Fig. 7B) and calcite biospheroids (Fig. 4L). The $\delta^{13} \mathrm{C}$ values confirm the presence of a relatively open environment $(<-8 \%)$. A vegetation change occurs during this phase: phytoliths from trees, especially dicotyledons, decrease and ash (Fraxinus sp.) appears in the charcoal assemblage. The related pedological features (Table.2) indicate a cumulic soil dynamic, resulting from the sufficient draining of the alluvial plain characterized by high evapo-transpiration (slight increase of the $\mathrm{BI}$ ' and $\mathrm{CaCO} 3$ rhizoliths).

The last sub-phase Lalo IVd (SP 9e-10) is associated with a deterioration of the leading flows. The new enlarged riverbed is characterized by the high lateral mobility of small, shallow channels and splay channels (Figs. 3 and 7A). The flows are characterized by high/very high energy (sandy to gravelly deposits), that evolve to gravelly braiding, before a new cutoff. Riverbed aggradation is locally very substantial and includes red fersiallitic soil aggregates and a high magnetic susceptibility value (Fig. 7A) that reflect simultaneous erosion of the Upper Quaternary terrace (Fig. 3) in association with fire events (Fig. 7B, Table 2). This period coincides with the first Cardial farming settlement in Lalo (7.65-7.43 ka).

Lalo V (SP 10a-b) was characterized by great stability in the floodplain. A brown palaeosoil (2.5Y 4/4) $15-20 \mathrm{~cm}$ thick is identified, extending from the bank to the floodplain (Fig. 3). The Cardial pits dug in this palaeosoil follow the overbank deposits, confirming the alluvial stability and showing that the Neolithic communities settled as close as possible to the active riverbed around 7.5-7.37 ka (max.probability of CPDF) (Fig. 6A). All indicators of pedogenesis are maximum (Table.2, Fig. 4E) and confirm that humidity and evapotranspiration was high, which could explain the low BI' value and the high rate of damp-meadow gastropods (Fig. 7B). This stability favoured the development of persistent forest vegetation across the floodplain, according to the phytolith data, to the rates of P. elegans (20\%) and shade-loving species (30\%) and to the charcoal assemblages (Figs. 5 and 7B). Deciduous oaks were always predominant. On the site, the presence of heliophilous and pre-forest species reflect local human impact on the vegetation (clearing) and explains the low value of $\delta^{13} \mathrm{C}$ (Figs. 5 and 7B). The enrichment in $\delta^{18} \mathrm{O}(-4 \%)$ values is evidence for a change in the origin of the rains (Mediterranean)

Lalo VIa (SP 11a-b): Alluviation began again around 7.37 ka with 


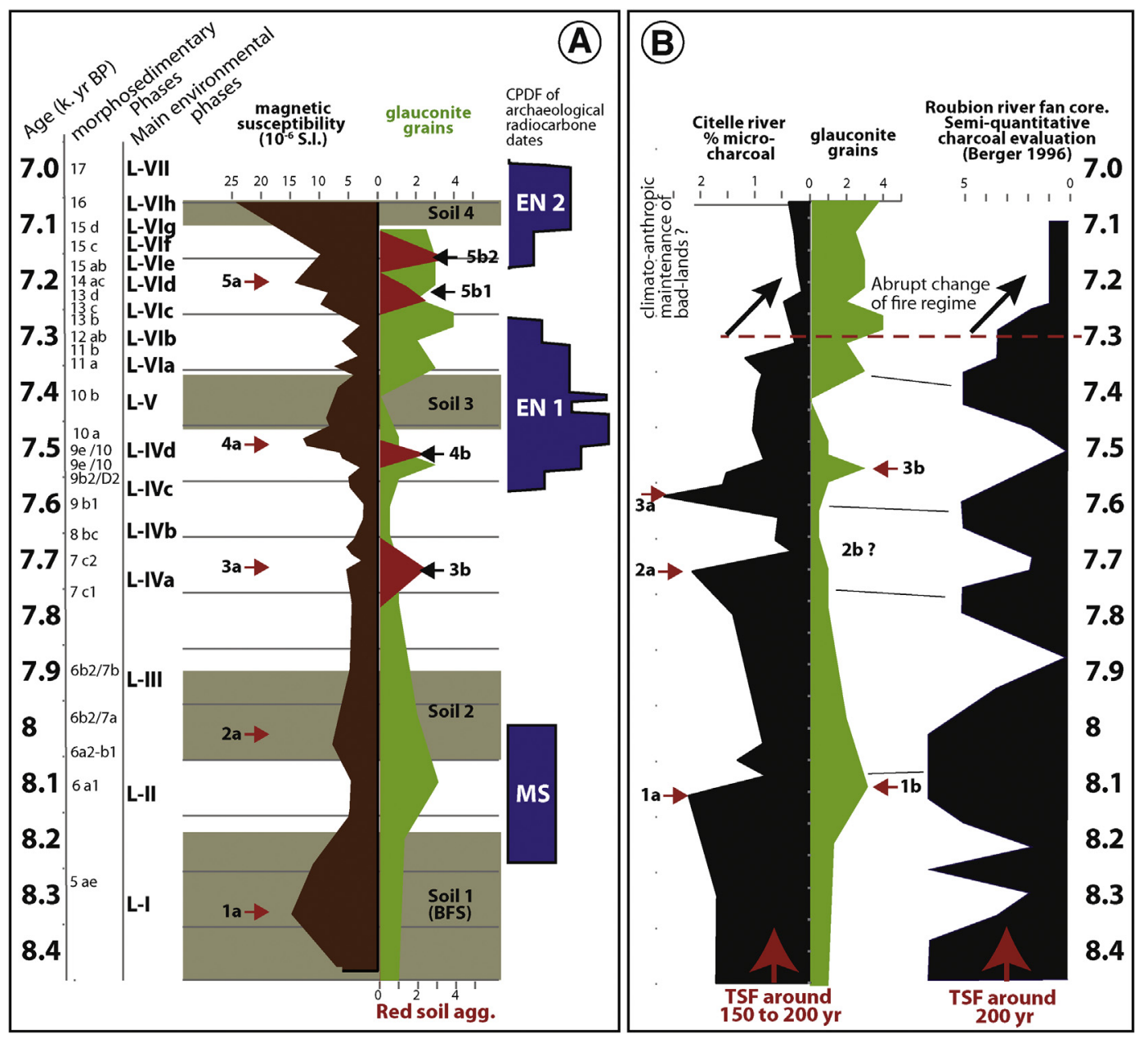

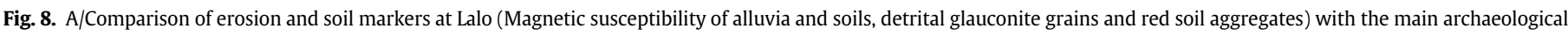

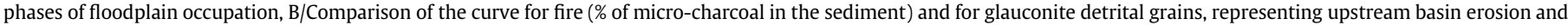
with fire events of the Roubion river fan (Berger, 1996). Fire chronology and Time-since-fire (TSF) of the 2 sites are very close.

high-energy flood deposits (sandy silt). The aggradation was rapid and abundant in the southern part (average $10 \mathrm{~mm} / \mathrm{year}$ ). The Albian-Aptian formations of the middle/upper basins are the main sources of erosion (crystic carbonated matrix, glaucony grains, bioclastic foraminiferous). The preservation of some irregular discontinuous beds reveals the speed of the fluvial aggradation. Compaction features with ferromanganese impregnations of soil matrix indicate a deterioration of the draining conditions (Table 2). The malacofauna mirrors this local hydromorphy, showing a strong increase in marsh and amphibious species in 11b (Fig. 6A and C, 7B). The charcoal assemblages confirm moister and possibly cooler conditions in the floodplain, indicated by the presence of Betulaceae (birch family), heliophilous species and trees growing on humid soils (Populus sp./Salix sp.). Given the local edaphic humidity observed, the small charcoal peak could be related to the use of fire for the maintenance of pastureland (rate of damp-meadow malacofauna between 60 and $80 \%$ ) at the expense of forest development (Figs. 6C and 7B). The Neolithic communities would have had to adapt their spatial organization to this rapid geomorphological change, while continuing to use it for their herds.

Around 7.31-7.28 ka (Lalo VIb, SP 12a-b), the expansion of the active band of the Citelle river in the south is related to an increase in the wide, shallow, high-energy channels made up of sand and gravel (W/D ratio from 12 to 22) (Fig. 3). A transformation towards gravelly to sandy braiding occurred, strongly eroding the underlying deposits. A fine crystic matrix of marl origin, rich in glaucony sands and rolled tufa fragments, indicates erosion of the sandy marl slopes and the destruction of travertine deposits. Drainage in the floodplain was degraded (Table 2). The dampmeadow species thus disappeared from the plain, while shadeloving species increased (Fig. 7B). This phase corresponds to a pronounced and durable decrease in the amount of micro-charcoal $(<0.2 \%)$ and to the disappearance of secondary carbonation, suggesting an atmospheric humidification that reduced the ETP process and the occurrence of fire while increasing lixiviation and riparian forest development.

The phases of Lalo VIc-VIh (SP, 13-16, 7.28 and $7.1 \mathrm{ka}$ ) indicate a long-lasting transformation of the floodplain dynamics. The subphases VIc-e-g correspond to a maximal enlargement of the active river bed, associated with the maximal energy of the flows (D99 $>0.1 \mathrm{~m})$ (Figs. 3 and 7A). An undulating morphology characterised the river, indicating that an active band expanded at that point in time over the entire alluvial plain ( $>100 \mathrm{~m}$ width). Braiding of the river occurred, with a coarse sandy to gravel load and very wide, shallow channels. It created typical lateral and oblique accretion structures. The abundance of weathered gravels and clay aggregates of fersiallitic soils in the alluvia (Figs. 4K and 7A) indicates a simultaneous erosion of Quaternary terraces, whose vegetation cover had probably been cleaned by Cardial settlements. This extreme lateral mobility of the riverbed over a limited, 
unconstrained area resembles a wandering channel pattern evolving towards a braided one (Nanson and Croke, 1992). Their W/ D ratio increases considerably (10-17.5) (Figs. 3 and 7A, Table 2). This very coarse, torrential style, alternating with sandy braiding (VId-f) and subject to a fine, silty-sandy, vertical aggradation that was abundant and rapid (average of $10 \mathrm{~mm} /$ year, Figs. 3 and 7a), is often associated with rolled Neolithic sherds and flint, indicating that the erosion of the Cardial settlement was continuing. Sandymarl Albian-Aptian formations are always the main erosion sources. Weathering processes and compaction features (hydromorphy) are dominating (Table 2). $\mathrm{CaCO} 3$ precipitations disappeared, and fire activity became minimal. All these environmental indicators illustrate a moister climate with a positive water budget. The high values of the rhizoliths' $\delta^{18} \mathrm{O}$, between -6 and $-7 \%$, reveal that permanent rain influences came from the North Atlantic.

An occasional decrease in flow energy and in solid loads participated in the formation of a fluvisol with granular structure, strong eluviation and weathering of the soil skeleton grains around $7.15 / 7.10 \mathrm{ka}$ (VIf). This temporary stability of the riverbed facilitated the rapid establishment in the floodplain of a permanent Epicardial settlement, indicated by numerous pits and post holes (Fig. 3). This population had probably taken refuge on the upper terraces during the most torrential phases. The following VIg phase is very short (a few decades?), centred on $7.1 \mathrm{ka}$, occurring between two Cardial occupations (Fig. 3, levels 2-3) with very close radiocarbon dates. As discussed above, the complete destruction of the third Cardial occupation level occurred in this phase.

Lalo phase VIh (about 7.07-7.05 ka) represents a transition with a high decrease in fluvial energy. This period is characterized by a short incision phase, over almost $1 \mathrm{~m}$, cutting through the alluvia of phases VIb-g (W/D ratio from 3.15 to 4.15). A wide braided pattern (W/D ratio $=14$ to 15 ) developed in the plain, sandy and shallow. The braiding morphology was then fossilized by coarse silts and fine greenish glaucony sand deposits, which crowned and sealed this mid-Holocene terrace before its definitive abandonment. These last alluvia are pedogeneized, contemporary to the last dense Epicardial settlement (level 3). Phytoliths and $\delta^{13} \mathrm{C}$ confirm that the landscape was more open (Figs. 5 and 7B), with Pinus sp. and evergreen Quercus presence (charcoal).

Lalo VII signals the final entrenchment of the riverbed south of the site from $7.05 \mathrm{ka}$, in the modern plain where it still flows 2-3 m farther down. This phase contributed to the formation of an Early/ Middle Holocene terrace, about $100 \mathrm{~m}$ wide, no longer affected by the hydro-sedimentary variations of the Citelle.

\section{Discussion}

The extreme mobility of the Citelle river and the clarity of the pedosedimentary archives enable a clear appreciation of the evolution of the basin and the local environments that succeeded each other. This sequence changes our perception of the first part of the mid-Holocene (8.5-7 ka), which was generally associated with a warm and humid climate optimum. Periods of high hydrosedimentary activity are manifested in two ways: (1) with braiding and sometimes anastomosis of the riverbeds or (2) with frequent floods, leading to rapid aggradation of the levees and the channel bottom and to the related rise of the aquifer and hydromorphic bioindicators. On the other hand, meandering is always linked with indicators of stability: (1) development of pedological processes across the alluvial plain, (2) entrenchment of the riverbed, (3) travertinisation of the river bed and (4) densification of the vegetation cover.

\subsection{Temporality and causality of the hydro- and pedosedimentary} processes during the mid-Holocene

The Lalo sedimentary archives illustrate the high sensitivity of the small pre-Alpine basins of the northern Mediterranean to the climatic and environmental variations of the Middle Holocene (rain regime, drought, fire activity). We note the extreme rapidity of stabilization of the sandy marl slopes because of pedological and vegetational developments as soon as the humidity increased and the frequency of fire decreased. After a bi-millennial stability during the Early Holocene (starting around $10.5 \mathrm{ka}$ ), the Citelle riverbed went through 10 metamorphoses in 14 centuries, between 8.5 and 7.05 ka (Figs. 3 and 7A). The dynamics accelerate, starting around $7.7 \mathrm{ka}$, because of an increase in the sedimentary flows, which regularly clogged the channels, resulting in a braided configuration. The main control variable for that period is the sedimentation rate, boosted by the fire regime in the upstream basin, whose slopes consisted of erodible soft rock substrates. From this period on, the floodplain is transformed at an average rate of once every half-century with considerable variations in the liquid and solid loads of the river. The strong discontinuity of the human Neolithic pressure partly explains this difference: the forest regenerated very quickly at the time, in parallel with the effects of the various climatic and orbital parameters (including increased seasonality, which undoubtedly constitutes a magnifying factor). Before $8.2 \mathrm{ka}$, the hydroclimatic cycles observed appear to have been less frequent (Early Holocene), less contrasted or less well recorded by the fluvial system. This increase in climatic and environmental variability at the beginning of the mid-Holocene has recently been discussed for the Mediterranean basin (Roberts et al., 2011; Peyron et al., 2011), at a point in time when the tropical/ Mediterranean humidity appears to have decreased up to 8.0/7.8 ka because of a change in the orbital forcing.

The observation of palaeosols throughout the floodplain provides evidence for Early/Middle Holocene floodplain stability phases that indicate response to regional climate change. Their pedological features indicate various environments and conditions of soil development (Figs. 3 and 4A/E, Table 2). The only developed soil identified in Lalo was formed between 10.5 and $8.2 \mathrm{ka}$ (Lalo 1). Palaeosols with the same characteristics are identified elsewhere in the Valdaine basin (Charols-Grand Bois, Berger, 2006). These buried humic and clay-rich dark soils are also found in Franche-Comté (north-east France) in the alluvial plains of the Seille and the Doubs (Rotillon, 2000) and in central Europe (Rittweger, 2000, Dambeck and Thiemeyer, 2002; Gerlach et al., 2012). Many sediment profiles from German floodplains highlight the occurrence of a socalled "Black Floodplain Soil" (BFS). Rittweger (2000) mentions 2 periods for the BFS development, the Early Holocene (Boreal) and the Middle Holocene (Late Atlantic period). Formerly described as relics of chernozemic soils and thus interpreted as climatically induced, their formation is now thought to be linked to anthropogenic impact, because of the presence of charred organic matter and their proximity to Middle Neolithic settlements (Delhon and Thiébault, 2009, Kadereit et al., 2010, Gerlach et al., 2012). However in Lalo (10.5-8.2 ka) they were formed early, during the first stage of the BFS, which is more in favour of a climatic determinism during the long period of floodplain stability, associated with regular fires and good natural drainage.

The other monophased palaeosols interstratified in the alluvia between 8.05 and 7.05 ka present distinctly less developed pedological features, such as limited thickness, weak pedality and weathering of calcite grains (Table 2, Fig. 4C/E), and can be described as fluvents (Soil Survey Staff, 2006) or cumulic fluviosoils (L-III, V, VII).

The considerable discontinuity of pedological evolution in 
Rhodanian fluvial environments clashes with the traditional pattern of the Atlantic interval, seen as biostatic. This means that the classic concept of pedogenesis during the Atlantic interval should probably be reconsidered, limited to the second part of the Middle Holocene (Late Atlantic) as the palaeosols identified to between 8.2 and 7.1 ka are not particularly developed (fluvisoils) and are often truncated or buried under the alluvia (Berger, 2006) of the Early Holocene (Boreal) (Rittweger, 2000, Berger, 2006).

The humidification of the climate (with increased seasonal contrasts), along with a probable pastoral use of the sandy-marl slopes during the Epicardial occupation of the site (circa 7.3-7.1 ka), maintained deteriorated landscapes upstream in the basin, thus favouring an upstream-downstream connectivity, a high flow regime and a rapid aggradation of the alluvial plain. The erosion of the soft rocks and of the Late Quaternary terraces and alluvial fans with fersiallitic soils began to occur at $7.75 \mathrm{ka}$. These erosion peaks coincided with an increase in the magnetic susceptibility of the alluvia and with the "Cardial" settlement in the floodplain and in the upper terrace (Fig. 7A).

\subsection{Fire: a control variable of landscape evolution}

The vegetation also varied, more in terms of structure than in terms of composition (at least regarding the woody cover). Oak forests, usually described as dense and homogenous, in the Citelle catchment area present variations in density, as indicated by malacological and phytolith assemblages. Fire, the evidence for which being micro-charcoal, is partly responsible for these changes. At the beginning of the sequence, fire occurred naturally, but beginning in $7.32 \mathrm{ka}$ and with an intensification of settlement, it probably resulted from a combination of Neolithic human activity and the climate.

In the region, fires may have played a significant role in the changes that occurred in the "Atlantic" forest cover (Berger, 1996), but its impact on the composition of the woody cover remained low (Delhon et al., 2010) as well as in the triggering of the erosive phases. Their frequency appears to have been particularly high around 8.1, 7.72, 7.57 and 7.32 ka (Figs. 7B and 8). Between these episodes, the fire regime decreased, at the same time as the pedological and vegetation covers regenerated. Thus, the principal fire phases had a recurrence interval of about 150-250 years, but the discontinuous fluvial age pattern makes it impossible to precisely evaluate the periodicity of fire events. These results appear close to the fire phases and Time-since-fire (TSF) of the Roubion river fan, few kilometers downstream (Figs. 1B and 8). In addition to the climatic factors, ecological parameters such as regeneration of the available plant fuel between two fire phases must be considered. At least 1.5 to 2 centuries are necessary for the vegetation to recover and provide the optimal conditions for flammability and combustion propitious for the triggering of fires (Clark, 1988; Olsen, 1981). Multi-proxy data demonstrate the close relationship between fires and erosion of pedological litters in the upstream catchment area of the Citelle (Fig. 7A). There is a possible connection between the occurrence of fires and the accumulation of secondary carbonates in the alluvia and fluvisols which indicates high evapotranspiration (Fig. 7A). Both are characteristic of dryer (particularly during the summer period, cf Vannière et al., 2011) and possibly warmer climate phases. Fires mainly affected deciduous oak forests between 8.1 and 7.32 ka. Fires can cross the temperate deciduous oak forests quite easily during periods of hydric stress (Campbell and Campbell, 2000). Hydroclimatic and ecological activity during the first part of the $\mathrm{MH}$ was related to a clearly more contrasting seasonality due to orbital forcing (Berger et Loutre, 1991; Vannière et al., 2011). Comparison with the few available data concerning fire events in the region (Fig. 8) demonstrates that the periods of high fire regime appear to be synchronous and reflect variations in the atmospheric and climatic activity in the NW Mediterranean basin that are responsible for periods of aridity. The positive fire signal observed around $8.1 \mathrm{ka}$ corresponds to high fire activity on a regional scale in the midMediterranean (Vannière et al., 2011; N 40-45 ) areas and in the dry western Mediterranean regions of eastern Spain (Davis and Stevenson, 2007). By $7.5 \mathrm{ka}$, fire activity only increased in northern Mediterranean regions ( $>\mathrm{N} 45^{\circ}$, Vannière et al., 2011). On the scale of the Mediterranean basin, the regional synchronicity between fire occurrence and climatic drought suggests that climate was the dominant influence upon fire regime during the Early/ Middle Holocene (Vannière et al., 2011).

The possible ecological impacts of fire regimes in the NW Mediterranean basin should be considered in order to understand the evolution of the Neolithic frontier and its densification (Berger, 2006; Berger and Guilaine, 2009). In the course of dryer periods marked by exceptional fires, landscapes could be opened to produce large surfaces which could then be exploited by new farming populations. In Lalo, humans do not appear to have played a decisive role in the propagation of fires during the 1500 years for which we have evidence. The fire chronology does not appear to correspond particularly with the occupation periods of the site of Lalo, which are representative on a regional scale (Manen and Sabatier, 2003). In fact, the evidence for fire clearly decreases when the occupation became denser in Lalo, around $7.2 \mathrm{ka}$ (Epicardial phase). The climate became abruptly moister starting in 7.4-7.35 ka (more abundant and regular hydrological flows, increasing soil hydromorphy), creating conditions less favourable to natural major fire events (Fig. 8).

\subsection{Characterization of the mid-Holocene rapid climatic changes in the middle Rhone valley}

Three periods of abundant hydrology with varied characteristics have been identified in the Citelle basin: the first around 8.2-8.05 ka (Lalo II), the second beginning in 7.7-7.49 ka (Lalo IV) and the third between 7.37 and $7.05 \mathrm{ka}$ (Lalo VI) (Fig. 7A and B). The first coincides with the $8.2 \mathrm{ka}$ event. Whereas it is well identified in the glacial and marine records, there is not yet much recorded evidence for its impact on the continental ecosystems (Magny et al., 2003; Frisia et al., 2006; Davis and Stevenson, 2007, Berger and Guilaine, 2009; Bordon et al., 2009; Peyron et al., 2011; Vannière et al., 2011; Glais et al., 2015). This event does not appear to have been recorded in the major alpine glaciers, as it took place during a period when these had retreated considerably (Le Roy, 2012). Starting in $8.2-8.1 \mathrm{ka}$, the dry climate suddenly changes. It is characterized by episodes of very concentrated rains, concurrent with a high fire regime, which caused violent and abundant erosion in the Citelle basin. Several episodes of torrential discharge follow one another in the floodplain and contributed to the rapid change of its morphology, while burying and damaging the Mesolithic Castelnovian site (Fig. 3). Fire frequency (2 peaks of activity), synchronous to low $\delta^{18} \mathrm{O}$ and $\delta^{13} \mathrm{C}$ values, reveals a major change in vegetation structure, and the rains mainly came from the North Atlantic (Fig. 7A and B).

The second period (7.7-7.05 ka) has not been considered to be part of the RCC until the present study, as it is not distinctly recognizable in the palaeoclimatic records from polar glaciers. This period follows almost 3 and a half centuries of pedosedimentary stability in the Citelle plain (8.05-7.7 ka), associated with a deep river entrenchment, reduced alluvial load, and in-situ biogeochemical carbonate production, with development of a welldrained, structured Cambic fluvisoil, rich in secondary calcium carbonates. This period shows a tripartite structure: two sub- 
phases of abundant hydrology (Lalo IV and VI), between which there was a short secular sub-phase of pedogenesis (phase $\mathrm{V}$ between 7.49 and $7.37 \mathrm{ka}$ ). Lalo IV phase (7.7-7.49 ka) corresponds to a fairly warm, humid climate, as shown by the frequency of the flow episodes and the high concentration of $\mathrm{CaCO} 3$ in the overbank alluvia and in the channel fills. Isotope ratios (Fig. 7B) support the theory of a simultaneous increase in the average temperatures and in precipitation.

The second long phase of high hydrological activity (7.37-7.05 BP) (Lalo VI) corresponds to a braided regime and to the considerable erosion of upstream formations of the catchment area (polyphased, major hydro-sedimentary event). Its chronology is well defined by 6 radiocarbon dates (Fig. 3). The total disappearance of the secondary carbonates and the very distinct decline of charcoal in alluvia (Fig. 7B) are evidence for a modification of the water budget. Oxygen isotopes and western European proxy-data confirm the North Atlantic source of abundant rains (Figs. 7B and 9), which strongly increase the liquid load in the catchment area. Trees intolerant of high temperatures (Betulaceae) were present at that time. The malacological spectra indicate an increase of marshy meadows and humid forests in the floodplain (Fig. 7B), while the pedological features show deterioration of the drainage conditions and accelerated aggradation of the floodplain. Major torrential episodes, which caused considerable truncations of the fluvial valley bottoms, are discernible on a regional scale during the same period (Berger and Brochier, 2000; Berger, 2006).

Records from south-eastern France (Fig. 1A) rarely provide evidence for the tripartite structure of this climatic phase. The north-Alpine records of Rhone activity show a very clear flood peak between 7.75 and $7.45 \mathrm{ka}$ in Lake Bourget (Arnaud et al., 2005). The karst of the Gardon cave (Bugey massif) indicates frequent and powerful floods contemporary to the Cardial Neolithic, around 7.45-7.3 ka (Sordoillet and Voruz, 2002). The travertine systems of the Vaucluse region show two even more pronounced detrital phases around 7.6-7.4 and 6.8-6.6 ka (Ollivier et al., 2006). Lake Ledro (northern Italy) shows a high lacustrine level around 7.3-7.1 ka (Magny et al., 2012). The Po river discharge to the Adriatic rose strongly around 7.7-7.5 ka (Fig. 9), revealing high erosion rates in the northern Italian basin up to mountain areas, which would have led to salinity changes in the surface of the Adriatic (Combourieu-Nebout et al., 2013).

The compiled data from fluvial systems of Great Britain (Macklin et al., 2010) and Germany (Hoffmann et al., 2008) show that geomorphic activity synchronously increased with a maximum at $7.47 \mathrm{ka}$, which also corresponds to higher lake levels in the Jura and the northern Alps (Magny, 2004), and to subfossil tree deposits in the Danube and Main rivers (Becker and Schirmer, 1977) (Fig. 9). The Vistula (Poland) and Belarus rivers reveal a clear hydrological change that occurred between 7.6 and $7.1 \mathrm{ka}$, associated with wider meanders, higher flood frequency and higher energy (Kalicki, 2006). A glacial advancement is well recorded in the Austrian Alps, particularly in the small and medium glaciers, around 7.75-7.5 ka and perhaps a little after $7.4 \mathrm{ka}$ in the Gepatsch region (Nicolussi and Patzelt, 2001; Spötl et al., 2010). Evidence for this event may also be seen in the higher percentage of hematite grains in the ice-rafted debris (IRD) records of the North Atlantic zone (Bond et al., 2001) and in the Nordic Sea (Rasmussen and Thomsen, 2010) suggesting a cooler climate during this phase, correlated with a higher influence of the north-western Atlantic system. It coincided (1) with a period of lower solar activity, (2) with the highest rate of change in annual insolation during the interval 80007000 cal BP (Zhao et al., 2010), and (3) with the final phase of deglaciation marked by overflows from proglacial lakes (Magny et Begeot, 2004).

All palaeohydrological data discussed here prove that a humid,

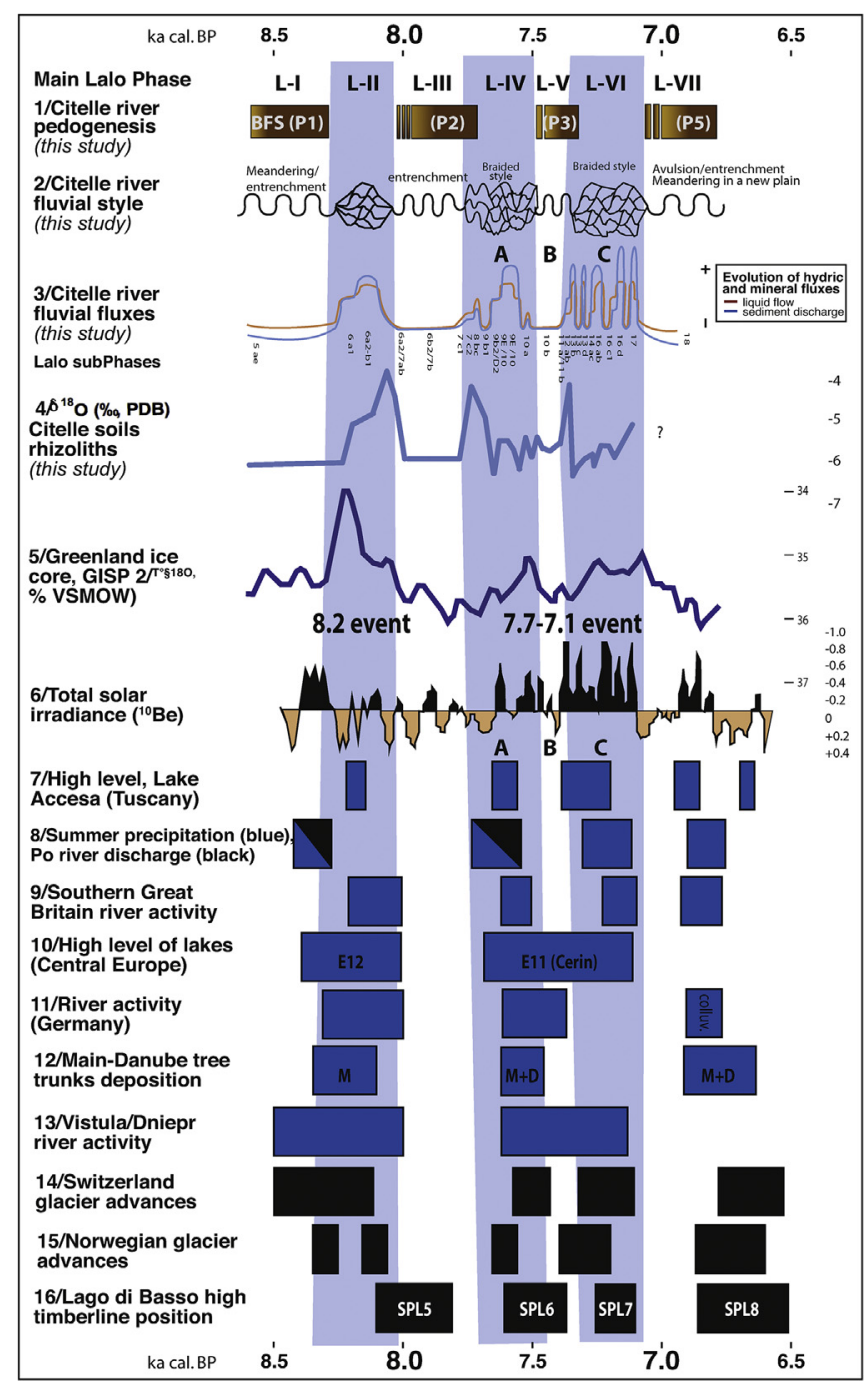

Fig. 9. Comparison of 1 /pedological, 2 /hydrogeomorphological, 3/palaeohydrological (hydric and solid flows), and 4/soil isotopic records of Citelle river in Lalo (this paper) with the main mid-Holocene European regional and global hydrological and palaeoclimate records (blue (West to Central Europe hydroclimatic signals) and black (Alpin data)), 5/oxygen isotope records from Greenland ice core GISP2 $\left(\mathrm{T}^{\circ} \S^{18} \mathrm{O}\right.$ ) (Alley et al., 1997), 6/Total solar irradiance based on ${ }^{10} \mathrm{Be}{ }^{14} \mathrm{C}$ in tree rings and polar ice cores, in $\left(\mathrm{W} / \mathrm{m}^{2}\right.$ ) (Steinhilber et al., 2012), 7/high levels of Lake Accesa, Tuscany, Italy (Magny et al., 2007), 8/Summer precipitation (blue), Po river discharge (black) according to smectite/kaolinite ratio in the Adriatic Sea (Combourieu-Nebout et al., 2013), 9/ southern Great Britain river activity (Macklin et al., 2010), 10/high level of lakes in Central Europe ( $\mathrm{E}=$ event, Magny, 2004), 11/Holocene river activity in Germany (Hoffmann et al., 2008), 12/Main-Danube tree trunks deposition periods (BeckerSchirmer 1977), M = Main, D = Danube, 13/Vistula/Dniepr river activity (Kalicki, 2006), 14/Switzerland glacier advances (Holzhauser, 2007), 15/Norwegian glacier advances (Nesje et al., 2001), 16/Lago di Basso timberline position, SPL = synchronous cold/ humid period (Haas et al., 1998). The blue bands correspond to colder periods in the Greenland ice sheet and alpine areas and to moister signals in western/central hydrosystems and to metamorphosed river bed to braided styles in the middle Rhone valley. A, B and C letters indicate the tripartite climate division of the 7.7-7.1 event. (For interpretation of the references to colour in this figure legend, the reader is referred to the web version of this article.)

cool climatic event took place in the middle of the 8th millennium BP (Fig. 9), but they often indicate only one major hydrological episode. The study of Lake Accesa (Tuscany, Italy) identifies three sub-phases between 7.65 and $7.2 \mathrm{ka}$ : two episodes of high lacustrine level occurring before and after an episode of relative decrease around 7.55-7.4 ka (Fig. 9, Magny et al., 2007). Two significant peaks in summer precipitations associated with a cooler climate 
occurred at 7.7 and $7.25 \mathrm{ka}$, indicated in the Adriatic Sea records (Combourieu-Nebout et al., 2013). The two episodes of glacial advancement from Frosnix-Misox in the Swiss Alps, around 7.58-7.42 and 7.32-7.0 ka (Holzhauser, 2007), the variations in factors SPL6 (7.6-7.35 ka) and SPL7 (7.25-7.1 ka) of the timberline at the site of Lago di Basso (Switzerland, Haas et al., 1998) and the slightly earlier episodes of the Norwegian glaciers (Nesje et al., 2001) during the same period, seem also to confirm a tripartite climate division (Fig. 9, A-B-C) - i.e. two cooler and more humid episodes occurring before and after a short, more temperate period. The alluvial sequence in Lalo clearly illustrates the tripartite division of this RCC in the middle Rhone valley: a succession of humiddry-humid, which echoes the temperature variations recorded in the core GISP2 from Greenland (Fig. 9), the rhythm of $\mathrm{Be}^{10}$ variation measured in ice cores and the total solar irradiance forcing (solar activity) (Fig. 9). The low lacustrine level phase identified in Tuscany corresponds to a drying-up phase in the alluvial plain of the Citelle, which favoured pedological development and the Cardial Neolithic settlement close to the river bed. All this data seem to establish that the middle Rhone valley, Tuscany and probably central Europe are to be included in the same climate zone during the first half of the mid-Holocene period.

\subsection{Impacts on and adaptations of the first Neolithic societies in the Rhone valley}

The site of Lalo contributes to the understanding of the evolution of the Early Neolithic in the Rhone catchment area. Final Mesolithic open-air sites were unknown in the low alluvial plain contexts of the Rhone. Only the mountainous areas of the Vercors attracted many hunting camps (Bintz et al., 1995). The few inventoried Castelnovian sites are situated in caves and rock shelters of calcareous Provence, often alongside watercourses (Vaucluse and Gard departments). Based on the few known sites, and despite the lack of precise chronological and climatic context, Binder (2000) formulates the hypothesis that the southern Castelnovian populations were concentrated as near as possible to the humid zones (marshes and rivers) and lacks any. In NE Spain (Bajo, Aragon) at the same time, the 8.2 ka event associated with a short and abrupt arid period caused the abandonment of the lower plains in favour of more humid habitats in the southern Iberian mountains (GonzálezSampériz et al., 2009).

The Cardial period (7.55-7.2 ka) appears to have been particularly unstable in the area, with rapid and regular hydrogeomorphic and environmental fluctuations. This situation explains the difficulty of identifying open-air settlements of the NW Mediterranean (Berger and Guilaine, 2009; Berger, 2011). The Epicardial period (7.2-6.8 ka) corresponds to the end of this major hydrosedimentary event (Berger, 2006). The beginning of the Epicardial expansion, around $7.25 \mathrm{ka}$, might thus be contemporary to a more humid and cold period, related to high instability and pressure in the riverbeds. The Cardial populations may have reacted by redistributing their settlements within the Rhone area, on the Quaternary terraces and alluvial fans, sheltered from the hydrological imbalances that affected the lower alluvial plain. Archaeological survey results around the Lalo site (Beeching, 2003) support this hypothesis (Fig. 1B). The stability and the drying-up of these floodplains are confirmed again starting in 7.1-7.05 ka with the incision of the hydrosystems (Fig. 9), which facilitated Epicardial settlement in the low alluvial plains of the middle Rhone valley (Berger, 2006, 2011) as well as in the Vistrenque plain in the eastern Languedoc (Perrin et al., 2009). The first farmers had to adapt to long periods of abundant water as well as to the drying-up of alluvial and marshy lands, a characteristic of the mid-Holocene period. The territory available was enlarged during the phases of meandering and pedogenesis, and reduced during the phases of braiding, when the active spaces of the floodplain strongly increased, thus reducing the amount of available land (Berger, 2006).

\section{Conclusions}

Floodplains provide the opportunity to examine fluvial processes and environmental history. We record changes in the types and amounts of flood sedimentation due to climatic and ecological changes. In this study we have been able to demonstrate (i) the effects of the Holocene RCCs on the manner in which the Rhone pre-Alpine basin functioned, (ii) the great variability in climate and environment at the beginning of the $\mathrm{MH}$, which regionally corresponded to a trend from a wetter to a drier climate (Roberts et al., 2011; Peyron et al., 2011), (iii) the influence of fire activity and frequency on the evolution of the vegetation cover, soil erosion and fluvial aggradation in the lower plains, and (iv) the major constraints that the Neolithic populations had to face in the floodplains during a RCC.

Hydroclimatic variability during the $\mathrm{MH}$ is expressed in the accelerated geomorphological evolution of the riverbeds. Their reactivity to the various stimuli, external (pluviometry, $\mathrm{T}^{\circ}$ ) and internal (morphology, W/S lithology, fire regime) is rapid and regular between 8.2 and $7.1 \mathrm{ka}$, in contrast to the almost two millennia of morpho-pedological stability (EH thermal optimum) that preceded it.

Around 7.35-7.30 ka, we observe a propagation of coarse load downstream. This is related to undoubtedly natural fires which caused the protective forest cover to decrease and open landscapes to increase, to burgeoning human pressure (Epicardial phase), probably due to activities that were more conspicuous on the slopes, and to an increase in precipitation generating exceptional hydrological conditions. The cooling and humid climate significantly reduced the fire regime and the ETP in the plains, while increasing hydromorphy.

This fluctuation is perceptible on a regional scale, in all kinds of systems (lakes, karsts, travertines, rivers, high altitude glaciers ...) (Fig. 9). Our results, supported by the continental, marine (IRD 5b) and glacier (GISP2) climate proxies on the scale of the hemisphere, as well as solar activity, confirm the existence of a long tripartite RCC (7.7-7.1 ka), which caused a more intense North Atlantic regime right in the middle of the 'thermal maximum' (well recorded in the oxygen isotope data of Lalo). This global cooling period is associated with a high pluviometric regime in the north-central Mediterranean (Zhornyak et al., 2011; Combourieu-Nebout et al., 2013). This 7.7-7.1 ka RCC appears to have been tripartite. A similar structure is observed for the 8.2 ka event (Tinner and Lotter, 2001; Magny et al., 2003). The response of a small fluvial system suchs the Citelle river to external impact was rapid and clearly correlates with the Greenland records (GISP2), and with North Atlantic thermohaline circulation and atmospheric changes (Fig. 9). The changes in the fluvial system imposed many constraints on the use of the fluvial passageways for the first Neolithic people, and led to the disappearance of many sites related to the Neolithisation process, probably including many of the earlier open-air settlements (Berger and Brochier, 2000, Berger and Guilaine, 2009). Thus, if the Cardial sites that have prevailed in scientific publications are those in caves and rock shelters, it is likely because they have more easily survived. This conclusion can probably be generalized to include other northern Mediterranean regions presenting the same record during the Mesolithic-Neolithic transition (Biagi and Spataro, 2002; Mlekluz et al., 2008). Further detailed study of valley bottoms during this pivotal period of European history will doubtless provide many more surprises for scholars. 


\section{Acknowledgements}

We thank J. Vital, F. Cordier and T. Bouquin for their help during field works and the rescue archaeological excavation on the Mediterranean TGV Lines, and Réseau Ferré de France and INRAP for their financial and logistic support. This paper has benefited from the financial support from the ACI program of the French Research Ministry "Les paléoincendies: origine, régime et impact sur le fonctionnement des eco-anthroposystèmes dans le bassin méditerranéen nord-occidental depuis le Tardiglaciaire" (J.F. Berger dir.). A part of the analysis have been made in the OMEAA plateforme of the UMR 5600 EVS-Lyon 2 University in the PaléomexArchéomede project (INEE-INSU). We thank E. Willcox for the translation work. This paper emerges as a result of a workshop at Costa Navarino and the Navarino Environmental Observatory (NEO), Greece in April 2014, addressing Mediterranean Holocene climate and human societies. The workshop was co-sponsored by PAGES, NEO, the MISTRALS/PaleoMex program, the Labex OT-Med, the Bolin Centre for Climate Research at Stockholm University, and the Institute of Oceanography at the Hellenic Centre for Marine Research. We thank the three anonymous reviewers and L. Lespez (LGP) for their constructive suggestions and editorial work, which greatly improved the manuscript.

\section{Appendix A. Supplementary data}

Supplementary data related to this article can be found at http:// dx.doi.org/10.1016/j.quascirev.2015.11.019.

\section{References}

Alley, R.B., Agustsdottir, A.M., 2005. The 8k event: cause and consequences of a major Holocene abrupt climate change. Quat. Sci. Rev. 24, 1123-1149.

Alley, R.B., Mayewski, P.A., Sowers, T., Stuiver, M., Taylor, K.C., Clark, P.U., 1997. Holocene climatic instability: a prominent, widespread event 8200 yr ago. Geology 25 (6), 483-486.

Arnaud, F. Revel, M., Chapron, E. Desmet, M., Tribovillard, N., 2005, 7200 years of Rhone river flooding activity in the Lake le Bourget: a high-resolution sediment record of NW Alps hydrology. Holocene 15, 420-428.

Arnaud, F., Révillon, S., Debret, M., et al., 2012. Lake Bourget regional erosion patterns reconstruction reveals Holocene NW European Alps soil evolution and paleohydrology. Quat. Sci. Rev. 51, 81-92.

Arnaud-Fassetta, G., Bruneton, H., Berger, J.-F., Baudouin, C., Boès, X., Provansal, M. 2005. Paleohydrology and environmental change in the Rhône Delta : a 8000yr record of paleohydrology and environmental change in fluvial-influenced sediments from Urban Arles-Piton core, North Rhône Delta, France. Z. für Geomorphol. 49 (4), 455-484.

Baldini, J.U.L., McDermott, F, Fairchild, IJ, 2002. Structure of the 8200-year cold event revealed by a speleothem trace element record. Science 296, 2203-2206.

Becker, B., Schirmer, W., 1977. Palaeoecological study on the Holocene valley developement of the River Main, Southern Germany, Boreas 6, 303-321.

Beeching, A., 2003. Le Néolithique entre Rhône moyen et Alpes. Synthèse de travaux présentée pour une candidature à l'obtention d'une HDR. Université de Lyon 2, Lumière, 167 pp., $74 \mathrm{pl}$

Beeching A., 2009. Les maisons ovales du Néolithique ancien de Lalo à Espeluche (Drôme). In: Beeching, A., Senepart, I. (Eds.), De la maison au village. L'habitat néolithique dans le Sud de la France et le Nord-Ouest méditerranéen, Mémoire XLVIII de la Société préhistorique française, pp. 39-48.

Berger, J.-F., 1996. Le cadre paléogéographique des occupations du bassin valdainais (Drôme) à l'Holocène. University of Paris 1. Doctoral dissertation.

Berger, J.-F., 2006. Sédiments, dynamique du peuplement et climat au Néolithique ancien. In: Guilaine, J. (Ed.), Populations néolithiques et environnements. Errance, Paris, pp. 155-212.

Berger, J.F., 2011. Hydrological and post-depositional impacts on the distribution of Holocene archaeological sites: the case of the Holocene middle Rhône River basin, France. Geomorphology 129 (3-4), 167-182.

Berger, J.-F., Brochier, J.-L., 2000. Évolution des paysages et des climats dans la moyenne vallée du Rhône et sa bordure préalpine de 13000 à 5000 BP. In: Les derniers chasseurs cueilleurs d'Europe occidentale (13000-5500 av. J.-C.), actes du Colloque international de Besançon, 23-25 octobre 1998. Presses universitaires Franc-Comtoises, Besançon, pp. 37-58 coll. Annales Littéraires.

Berger, J.-F., Guilaine, J., 2009. The 8200 calBP abrupt environmental change and the Neolithic transition: a Mediterranean perspective. Quat. Int. 200, 31-49.

Berger, A., Loutre, M.F., 1991. Insolation values for the climate of the last 10 million of years. Quat. Sci. Rev. 10, 297-317.
Berger, J.F., Salvador, P.G., Franc, O., Vérot-Bourrely, A., Bravard, J.P., 2008. La chronologie fluviale postglaciaire du haut bassin rhodanien. Coll. EDYTEM n 6 , Cah. Paléoenvironnement 117-144.

Biagi, P., Spataro, M., 2002. The Mesolithic/Neolithic transition in North eastern Italy and in the adriatic Basin. In: Badal- Garcia, E., Bernabeu Auban, J., Marti Oliver, B. (Eds.), El paisage en el Neolitico mediterraneo. Universitat de Valencia (Saguntum Extra-5), Valencia, pp. 167-178.

Binder, D., 2000. Mesolithic and Neolithic interaction in southern France and northern Italy: new data and current hypotheses. In: Price, T.D. (Ed.), Europe's First Farmers. Cambridge University Press, pp. 117-143.

Bintz, P., Picavet, R., Evin, J., 1995. L'évolution culturelle du Mésolithique au Néolithique moyen en Vercors et dans les Alpes du Nord. In: Voruz, J.L. (Ed.) Chronologies néolithiques. De 6000 à 2000 avant notre ère dans le bassin rhodanien, vol. 20. Doc. du département d'Anthropologie de l'Université de Genève, pp. 41-53.

Blanchet, G., 1990. Régimes météorologiques et diversité climatique dans l'espace rhonalpin. Rev. Géogr. Lyon 106-117.

Bond, G., Kromer, B., Beer, J., Muscheler, R., Evans, M.N., Showers, W., Hoffmann, S., Lotti-Bond, R., Hajdas, I., Bonani, G., 2001. Persistent solar influence on north Atlantic climate during the Holocene. Science 294, 2130-2136.

Bonté, S., 2006. Caractérisation des climats et des environnements rhodaniens postglaciaires par l'analyse des isotopes stables $\left(\delta^{18} \mathrm{O}\right.$ et $\left.\delta^{13} \mathrm{C}\right)$ des carbonates pédologiques. Thèse de 3eme cycle. Université d'Avignon.

Bordon, A., Peyron, O., Lezine, A.-M., Brewer, S., Fouache, E., 2009. Pollen-inferred late-glacial and holocene climate in southern Balkans (Lake Maliq). Quat. Int. $200,19-30$

Bravard, J.P., 2010. Discontinuities in braided patterns: the River Rhone from Geneva to the Camargue delta before river training. Geomorphology 117, 219-233.

Bravard, J.-P., Verot-Bourrely, A., Franc, O., avec la collaboration de Arlaud, C., 1997. Paléodynamique du site fluvial de Lyon depuis le Tardiglaciaire. In: Dynamique du paysage : entretiens de géoarchéologie (J.P. Bravard, and M. Prestreau, éd.) Actes de la table ronde “ Dynamique du paysage : entretiens de géoarchéologie ", Lyon 17 et 18 novembre 1995. Documents de l'Archéologie de Rhône-Alpes, 15 , pp. $177-202$

Brémond, L., Alexandre, A., Peyron, O., Guiot, J., 2005. Grass water stress estimated from phytoliths in West Africa. J. Biogeogr. 32, 311-327.

Bronk Ramsey, C., 2005. OxCal Progam v3.10. http://c14.arch.ox.ac.uk/embed.php? File $=$ oxcal.html.

Brown, A.G., 1997. Alluvial Geoarchaeology. Cambridge University Press, Cambridge.

Bullock, P., Fedoroff, N., Jongerius, A., Stoops, G., Tursina, T., 1985. Handbook for Soil Thin Section Description. Waine Research Publications, Albrighton.

Campbell, I.D., Campbell, C., 2000. Late Holocene vegetation and fire history at the southern boreal forest margin in Alberta, Canada. Palaeogeogr. Palaeoclimatol. Palaeoecol. 164 (1), 263-280.

Canti, M.G., 2003. Earthworm activity and archaeological stratigraphy: a review of products and processes. J. Archaeol. Sci. 30, 135-148.

Carrión, J.S., 2002. Patterns and processes of Late Quaternary environmental change in a montane region of southwestern Europe. Quat. Sci. Rev. 21 (18), 2047-2066.

Cerling, T.E., 1984. The stable isotopic composition of modern soil carbonate and its relationship to climate. Earth Planatery Sci. Lett. 71, 229-240.

Cerling, T.E., Quade, J., 1993. Stable carbon and oxygen isotopes in soil carbonates. Climate change in continental isotopic records. Geophys. Monogr. 78, 217-231.

Clark, J.S., 1988. Effect of climate change on fire regimes in northwestern Minnesota. Nature 334, 233-235.

Combourieu-Nebout, N., Peyron, O., Bout-Roumazeilles, V., Goring, S., Dormoy, I., Joannin, S., Sadori, L., Siani, G., Magny, M., 2013. Holocene vegetation and climate changes in the central Mediterranean inferred from a high-resolution marine pollen record (Adriatic Sea). Clim. Past 9 (5), 2023-2042.

Courty, M.A., 1994. Le cadre paléogéographique des occupations humaines dans le bassin du haut-Khabur (Syrie du Nord-Est). Premiers résultats. Paléorient 20 (1), 21-59.

Cremaschi, M., Nicosia, C., 2012. Sub-Boreal aggradation along the Apennine marginof the Central Po Plain: geomorphological and geoarchaeological aspects. Géomorphologie relief, Process. Environ. 2, 155-174.

Dambeck, R., Thiemeyer, H., 2002. Fluvial history of the northern Upper Rhine River (southwestern Germany) during the Lateglacial and Holocene times. Quat. Int. 93, 53-63.

Davis, B.A., Stevenson, A.C., 2007. The 8.2 ka event and Early-Mid Holocene forests, fires and flooding in the Central Ebro Desert, NE Spain. Quat. Sci. Rev. 26 (13), $1695-1712$.

Dearing, J., 1999. Environmental Magnetic Susceptibility: Using the Bartington MS2 System, second ed. Chi Publishing, Kenilworth, UK.

Delhon, C., 2005. Palaeo-ecological reliability of pedo-anthacological assemblages. In: Dufraisse, A. (Ed.), Charcoal Analysis: New Analytical Tools and Method Papers from the Table-ronde Held in Basel, 2004, British Archaeological Reports, International Series, 1483, pp. 9-24

Delhon, C., 2007. Phytolith and pedoanthracological analysis of « off site » Holocene sequences from Mondragon (middle Rhone valley, South of France). In: Madella, M., Zurro, D. (Eds.), Plants, People and Places: Recent Studies in Phytolithic Analysis. Papers of the 4th International Meeting on Phytolith Research. Oxbow Books, Cambridge, pp. 173-188 august 2002.

Delhon, C. Thiébault, S., 2008. An approach to Holocene vegetation history in the middle Rhone valley (France): anthracological data from the « TGVMéditerranée " excavations. In: Fiorentino, G. (Ed.), Charcoal from the Past, 
Cultural and Palaeoenvironmental Implications. Proceedings of the Third International Meeting of Anthracology, Cavallino - Lecce (Italy), June 28th - July 1st 2004, British Archaeological Report International Series, 1807, pp. 63-73.

Delhon, C., Thiébault, S., 2009. De la forêt aux foyers Paléolithiques et Mésolithiques dans le Sud de la France et la moyenne vallée du Rhône : une revue des données anthracologiques et phytolithiques. In: Théry-Parisot, I., Costamagno, S. (Eds.), Gestion des combustibles, fonctions et fonctionnement des foyers au Paléolithique et au Mésolithique, fonctions de sites : nouveaux outils, nouvelles interprétations. Papers of the workshop WS21, XVth UISPP meeting, Lisbonne, september 2006, British Archaeological Reports, 1914, 119-113.

Delhon, C., Alexandre, A., Berger, J.F., Thiébault, S., Brochier, J.L., Meunier, J.D., 2003. Phytolith assemblages as a promising tool for reconstructing Mediterranean Holocene vegetation. Quat. Res. 59 (1), 48-60.

Delhon, C., Thiébault, S., Brochier, J.-L., Berger, J.-F., 2010. Dynamiques de végétation au Tardiglaciaire et à l'Holocène ancien en moyenne vallée du Rhône d'après les données les données anthracologiques. Quaternaire 21 (3), 281-293.

Delorme, A., Leuschner, H.H., 1983. Dendrochronologische Befunde zur jüngeren Flussgeschichte von Main, Fulda, Lahn und Oker. Eiszeitalter u. Gegenwart 33, 45-57.

Erkens, G., Dambeck, R., Volleberg, K.P., Bourman, T.I.J., Bos, J.A.A., Cohen, K.M., Wallinga, J., Hoek, W.Z., 2009. Fluvial terrace formation in the northern Upper Rhine Graben during the last 20000 years as a result of allogenic controls and autogenic evolution. Geomorphology 103, 476-495.

Evans, J.G., 1972. Land Snails in Archaeology. Seminar Press, London, New York

Fleitmann, D., Burns, S., Mangini, A., Mudelsee, M., Kramer, J., Villa, I., Neff, U., AlSubbary, A., Buettner, A., Hippler, D., Matter, A., 2007. Holocene ITCZ and Indian monsoon dynamics recorded in stalagmites from Oman and Yemen (Socotra). Quat. Sci. Rev. 26, 170-188.

Fleitmann, D., Mudelsee, M., Burns, S.J., Bradley, R.S., Kramers, J., Matter, A., 2008. Evidence for a widespread climatic anomaly at around 9.2 ka before present Paleoceanography 23, PA1102. http://dx.doi.org/10.1029/2007PA001519.

Frisia, S., Borsato, A., Mangini, A., Spötl, C., Madonia, G., Sauro, U., 2006. Holocene climate variability in Sicily from a discontinuous stalagmite record and the Mesolithic to Neolithic transition. Quat. Res. 66, 388-400.

Gerlach, R., Fischer, P., Eckmeier, E., Hilgers, A., 2012. Buried dark soil horizons and archaeological features in the Neolithic settlement region of the Lower Rhine area, NW Germany: formation, geochemistry and chronostratigraphy. Quat. Int. 265, 191-204.

Glais, A., López-Sáez, J.A., Lespez, L., Davidson, R., 2015. Climate and human-environment relationships on the edge of the Tenaghi-Philippon marsh (Northern Greece) during the Neolithization process. Quat. Int. http:// dx.doi.org/10.1016/j.quaint.2015.07.032.

González-Sampériz, P., Utrilla, P., Mazo, C., Valero-Garcés, B., Sopena, M.C., Morellón, M., Sebastián, M., Moreno, A., Martínez-Bea, M., 2009. Patterns of human occupation during the early Holocene in the Central Ebro Basin (NE Spain) in response to the 8.2 ka climatic event. Quat. Res. 71 (2), 121-132.

Guilaine, J., 1996. La néolithisation de la Méditerranée occidentale. In: Grifoni, R. Guilaine, J., L'Helgouach, J. (Eds.), The Neolithic in the Near East and Europe, Colloquium XVIII, XIIIe UISPP Congress. ABACO, Forli, pp. 53-68.

Guilbert, R., Beeching, A., Cordier, F., 2010. L'industrie lithique du site castelnovien de plein-air d'Espeluche-Lalo (Drôme) : spécificités techniques et culturelles. In: Economie et société de la fin de la Préhistoire, actualité de la recherche, actes des 7eme rencontres méridionales de préhistoire récente, 3-4 nov. 2006, pp. 173-186 dir. Beeching, A., Thirault, E., Vital J.

Haas, J.N., Richoz, I., Tinner, W., Wick, L., 1998. Synchronous Holocene climatic oscillations recorded on the Swiss Plateau and at timberline in the Alps. Holocene 8, 301-309.

Hoek, W.Z., Bos, J.A.A., 2007. Early Holocene climate oscillations-causes and consequences. Quat. Sci. Rev. 26, 1901-1906.

Hoffmann, T., Lang, A., Dikau, R., 2008. Holocene river activity: analysing 14C-dated fluvial and colluvial sediments from Germany. Quat. Sci. Rev. 27, 2031-2040.

Holzhauser, $\mathrm{H}$., 2007. Holocene glacier fluctuations in the Swiss Alps. In: Mordant, C., Richard, H., Magny, M. (Eds.), Environnements et cultures à l'Âge du Bronze en Europe occidentale. CTHS, Paris, pp. 29-43.

Jorda, M., Miramont, C., Rosique, T., Sivan, O., 2002. Evolution de l'hydrosystème durancien (Alpes du Sud, France) depuis la fin du Pléniglaciaire supérieur. In: Bravard, J.-P., Magny, M. (Eds.), Des rivières et des lacs de Lascaux à nos jours. Éditions Errance, Paris, pp. 239-249.

Kadereit, A., Kuhn, P., Wagner, G., 2010. Holocene relief and soil changes in loess covered areas of south-western Germany - the pedosedimentary archives of Bretten-Bauerbach (Kraichgau). Quat. Int. 222, 99-119.

Kalicki, T., 2006. Reflection of climatic changes and human activity and their role in the Holocene evolution of Central European valleys. Pr. Geogr. 204, 1-347 (in Polish).

Kalis, A.J., Merkt, J., Wunderlich, J., 2003. Environmental changes during the Holocene climatic optimum in central Europe e human impact and natural causes. Quat. Sci. Rev. 22, 33-79.

Kozarski, S., 1991. Warta, a case study of a lowland river. In: Starkel, L., Gregory, K.J., Thornes, J.B. (Eds.), Temperate Palaeohydrology. Wiley, Chichester, pp. 189-215.

Le Roy, M., 2012. Reconstitution des fluctuations glaciaires holocènes dans les Alpes occidentales. Apports de la dendrochronologie et des datations par isotopes cosmogéniques produits in situ. Thèse de géographie. Univ. de Grenoble, p. 390.

Macklin, M.G., 1999. Holocene river environments in prehistoric Britain : human interaction and impact. Quat. Proc. 7, 521-530.

Macklin, M.G., Jones, A.F., Lewin, J., 2010. River response to rapid Holocene environmental change: evidence and explanation in British catchments. Quat Sci. Rev. 29, 1555-1576.

Magny, M., 2004. Holocene climate variability as reflected by mid-European lakelevel fluctuations and its probable impact on prehistoric human settlements. Quat. Int. 113, 65-79.

Magny, M., Bégeot, C., 2004. Hydrological changes in the European midlatitudes associated with freshwater outbursts from Lake Agassiz during the Younger Dryas event and the early Holocene. Quat. Res. 61, 181-192.

Magny, M., Bégeot, C., Guiot, J., Peyron, O., 2003. Contrasting patterns of hydrological changes in Europe in response to Holocene climate cooling phases. Quat. Sci. Rev. 22, 1589-1596.

Magny, M., de Beaulieu, J.-L., Drescher-Schneider, R., et al., 2007. Climatic oscillations in central Italy during the Last Glacial-Holocene transition: the record from Lake Accesa. J. Quat. Sci. 21, 311-320.

Magny, M., Joannin, S., Galop, D., Vannière, B., Haas, J.N., Bassetti, M., Bellintani, P., Scandolari, R., Desmet, M., 2012. Holocene palaeohydrological changes in the horthern Mediterranean borderlands as reflected by the lake-level record of Lake Ledro, northeastern Italy. Quat. Res. 77, 382-396.

Manen, C., Sabatier, P., 2003. Chronique radiocarbone de la Néolithisation en Méditerranée nord-occidentale. Bull. la Soc. Préh. Fr. 100 (3), 479-504.

Mayewski, P.E., Rohling, J., Stager, W., Karlén, K., Maasch, L., Meeker, E., Meyerson, F. Gasse, S., van Kreveld, K., Holmgren, J., Lee-Thorp, G., Rosqvist, F., Rack, M. Staubwasser, R., Schneider, R., Steig, E., 2004. Holocene climate variability. Quat. Res. 62, 243-255.

Messager, E., Lordkipanidze, D., Delhon, C., Ferring, C.R., 2010. Palaeoecologica implications of the lower pleistocene phytolith record from the Dmanisi site Georgia). Palaeogeography, Palaeoclimatology. Palaeoecology 288 (1/4), 1-13.

Mlekluz, D., Budja, M., Payton, R., Bonsall, C., 2008. "Mind the Gap": caves, radiocarbon sequences, and the mesolithic- neolithic transition in Europe-Lessons from the Mala Triglavca Rockshelter site. Geoarchaeology 23 (3), 398-416.

Nanson, G.C., Croke, J.C., 1992. A genetic classification of floodplains. Geomorphology 4, 459-486.

Nesje, A., Matthews, J.A., Dahl, S.O., Berrisford, M.S., Andersson, C., 2001. Holocene glacier fluctuations of Flatbreen and winter-precipitation changes in the Jostedalsbreen region, western Norway, based on glaciolacustrine sediment records. Holocene 11, 267-280.

Nicolussi, K., Patzelt, G., 2001. Untersuchungen zur holozänen gletscherentwicklung von Pasterze und Gepatschferner (Ostalpen). Z. für Gletscherkd. Glazialgeol. 36, $1-87$.

Ollivier, V., Guendon, J.L., Adam, A., Roiron, P., Ambert, P., 2006. Evolution postglaciaire des environnements travertineux provencaux et alpins: nouveau cadre chronologique, faciès et dynamiques morphosédimentaires. Quaternaires 17 (2), 51-67.

Olsen, J., 1981. Carbon balance in relation to fire regimes. Technical Coordinators HA Mooney, TM Bonnicksen, NL Christensen, JE Lotan, WA Reiners. In: Proceedings of the Conference Fire Regimes and Ecosystem Properties. USDA, pp. 327-378 Forest Service General Technical Report WO-26.

Perrin, T., Bellot-Gurlet, L., Bonnardin, S., et al., 2009. Le Mas de Vignoles X (Nîmes, Gard) : un habitat de plein air du Néolithique ancien. In: Perrin, T., Thirault, É. Bonnardin, S. (Eds.), Marges, frontières et transgressions. Actualité de la recherche. Actes des 8e Rencontres Méridionales de Préhistoire Récente. Sénépart I., Marseille 2008, pp. 221-238.

Peyron, O., Goring, S., Dormoy, I., Kotthoff, U., Pross, J., de Beaulieu, J.-L., DrescherShneider, R., Vannière, B., Magny, M., 2011. Holocene seasonality changes in the central Mediterranean region reconstructed from the pollen sequences of Lake Accesa (Italy) and Tenaghi Philippon (Greece). Holocene 21, 131-146.

Piperno, D., 1998. Palaeoethnobotany in the Neotropics from micro-fossils: new nsights into ancient plant use and in the New World tropical forest. J. World Prehistory $12,393-449$.

Puisségur, J.-J., 1976. Mollusques continentaux quaternaires de Bourgogne. Significations stratigraphiques et climatiques. Rapports avec d'autres faunes boréales de France (Doin, Paris).

Rasmussen, T.L., Thomsen, E., 2010. Holocene temperature and salinity variability of the Atlantic water inflow to the Nordic Seas. Holocene 8, 1223-1234.

Richard, K., 1982. Rivers, Form and Process in Alluvial Channels. Methuen, Londres, p. 361.

Rittweger, H., 2000. The "Black Floodplain Soil" in the Amoneburger Becken, Germany: a lower Holocene marker horizon and indicator of an upper Atlantic to Subboreal dry period in Central Europe? Catena 41, 143-164.

Roberts, N., Brayshaw, D.J., Kuzucuoglu, C., Perez, R., Sadori, L., 2011. The midHolocene climatic transition in the Mediterranean Causes and consequences. Holocene 21 (1), 3-13.

Roberts, N., Jones, M.D., Benkaddour, A., Eastwood, W.J., Filippi, M.L., Frogley, M.R., Lamb, H.F., Leng, M.J., Reed, J.M., Stein, M., Stevens, L., Valero-Garce, B. Zanchetta, G., 2008. Stable isotope records of Late Quaternary climate and hydrology from Mediterranean lakes: the ISOMED synthesis. Quat. Sci. Rev. 27, 2426-2441.

Rohling, E.J., Pälike, H., 2005. Centennial scale climate cooling with a sudden cold event around 8,200 years ago. Nature 434, 975-979.

Romanek, C.S., Grossman, E.L., Morse, J.W., 1992. Carbon isotopic fractionation in synthetic aragonite and calcite: effects of temperature and precipitation rate Geochimica Cosmochimica Acta 56, 419-430.

Rotillon, S., 2000. L'ajustement des systèmes fluviaux de la fin du Tardiglaciaire au début de l'Holocène en tant qu'indicateur des changements environnementaux la Seille à l'aval d'Arlay (Jura, France). In: Actes du colloque international 
"Epipaléolithique et Mésolithique ; les derniers chasseurs cueilleurs d'Europe occidentale”, Besançon, oct. 1998. Annales Littéraires, 699. Presse Universitaire Franc-Comtoises 83 à 92, pp. 83-92.

Rozanski, K., Araguas-Araguas, L., Gonfiantini, R., 1993. Isotopic patterns in modern global precipitation. In: Swart, P.K., Lohmann, K.C., McKenzie, J., Savin, S. (Eds. Climate Change in Continental Isotopic Records, Geophysical Monograph, 78, p. 1236.

Sadori, L., Narcisi, B., 2001. The Postglacial record of environmental history from Lago di Pergusa, Sicily. Holocene 11 (6), 655-670.

Salomons, W., Goudie, A., Mook, W.G., 1978. Isotopic composition of calcrete deposits from Europe, Africa and India. Earth Surf. Process. 3 (1), 43-57.

Salvador, P.-G., Berger, J.-F., 2014. The evolution of the Rhone River in the Basses Terres basin during the Holocene (Alpine foothills, France). Geomorphology 204, 71-85.

Schumm, S.A., 1977. The Fluvial System. Wiley and Sons, New-York.

Sivan, O. Miramont, C. 2008. Les variations temporelles et spatiales de morphogenèse postglaciaire des fonds de vallons sud-alpins. L'exemple du bassin versant du Drouzet (Hautes-Alpes, France). Quaternaire 19 (3), 229-238.

Soil Survey Staff, 2006. Keys to Soil Taxonomy, tenth ed. USDA-Natural resources Conservation Service, Washington, DC, USA, p. 332.

Sordoillet, D., Voruz, J.L., 2002. Influence des fluctuations climatiques sur l'exsurgence du Gardon (Ambérieu-en-Bugey, France). In: Bravard, J.-P., Magny, M. (Eds.), Histoire des rivieres et des lacs de Lascaux à nos jours. Les fleuves on une histoire. Paléoenvironnement des rivières et des lacs français depuis 15000 ans. Coll. Archéologie aujourd'hui, Ed. Errance, Paris, pp. 171-184.

Spötl, C., Nicolussi, K., Patzelt, G., Boch, R., 2010. Humid climate during deposition of sapropel 1 in the Mediterranean Sea: Assessing the influence on the Alps. Glob. Planet. Change 71, 242-248.

Starkel, L., 1983. The reflection of hydrologic changes in the fluvial environment of the temperate zone during the last 15000 years. In: Gregory, K.J. (Ed.), Background to Palaeohydrology. Wiley, Chichester, pp. 213-235.

Starkel, L., Soja, R., Michczynska, D.J., 2006. Past hydrological events reflected in the Holocene history of Polish rivers. Catena 66, 24-33.

Steinhilber, F. Abreu, J.A., Beer, J., Brunner, I., Christl, M., Fischer, H., Heikkila, U., Kubik, P.W., Mann, M., McCracken, K.G., Miller, H., Miyahara, H., Oerter, H.
Wilhelms, F., 2012. 9,400 Years of cosmic radiation and solar activity from ice cores and tree rings. Proc. Natl. Acad. Sci. U. S. A. 109, 5967-5971.

Strömberg, C.A.E., Werdelin, L., Friis, E.M., Saraç, G., 2007. The spread of grassdominated habitats in Turkey and surrounding areas during the Cenozoic: phytolith evidence. Palaeogeography, Palaeoclimatology. Palaeoecology 250, $18-49$.

Tinner, W., Lotter, A.F., 2001. Central European vegetation response to abrupt climate change at $8.2 \mathrm{ka}$. Geology 29, 551-554.

Toonen, W.H.J., Kleinhans, M.G., Cohen, K.M., 2012. Sedimentary architecture of abandoned channel fills. Earth Surf. Process. Landforms 37, 459-472.

Twiss, P.C., Suess, E., Smith, R., 1969. Morphology classification of grass phytoliths. Proc. Soil Sci. Soc. Am. 33, 109-115.

Vannière, B., Power, MJ., Roberts, N., Tinner, W. Carrión, J., Magny, M., Bartlein, P. 2011. Circum-Mediterranean fire activity and climate changes during the mid Holocene environmental transition (8500-2500 cal yr BP). Holocene 21 (1), $53-73$.

Vött, A., Brückner, H., Handl, M., Schriever, A., 2006. Holocene palaeogeographies of the Astakos coastal plain (Akarnania, NW Greece). Palaeogeogr. Palaeoclimatol. Palaeoecol. 239, 126-146.

Welter-Schultes, F.W., 2012. European Non-marine Molluscs, a Guide for Species Identification. Planet Poster Editions, Göttingen.

Weninger, B., Alram-Stern, E., Bauer, E., Clare, L., Danzeglocke, U., Jöris, C., Kubatzki, C., Rollefson, G., Todorova, H., van Andel, T., 2006. Climate forcing due to the 8200 cal yr BP event observed at Early Neolithic sites in the eastern Mediterranean. Quat. Res. 66, 401-420.

Zhao, C., Yu, Z., Zhao, Y., 2010. Holocene climate trend, variability, and shift documented by lacustrine stable-isotope record in the northeastern United States. Quat. Sci. Rev. 29, 1831-1843.

Zhornyak, L.V., Zanchetta, G., Drysdale, R.N., Hellstrom, J.C., Isola, I., Regattieri, E., Piccini, L., Baneschi, I., Couchoud, I., 2011. Stratigraphic evidence for a "pluvial phase" between ca. 8200-7100 ka from Renella cave (Central Italy). Quat. Sci. Rev. 30, 409-417.

Zielhofer, C., Faust, D., 2008. Mid- and late Holocene fluvial chronology of Tunisia. Quat. Sci. Rev. 27 (5-6), 580-588. 